This is an Open Access article, distributed under the terms of the Creative Commons AttributionNonCommercial-ShareAlike licence (http://creativecommons.org/licenses/by-nc-sa/4.0/), which permits noncommercial re-use, distribution, and reproduction in any medium, provided the same Creative Commons licence is included and the original work is properly cited. The written permission of Cambridge University Press must be obtained for commercial re-use.

\title{
Spearheading into the Neolithic: Last Foragers and First Farmers in the Dinaric Alps of Montenegro
}

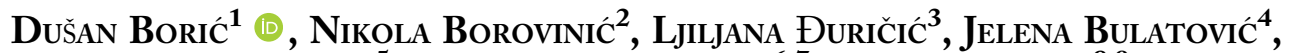

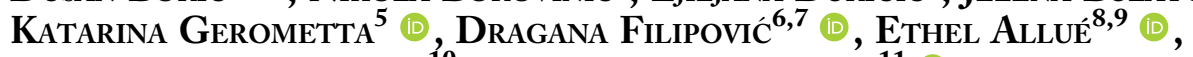 \\ Zvezdana Vušović-Lučićc ${ }^{10}$ and Emanuela Cristiani ${ }^{11}$ \\ ${ }^{1}$ The Italian Academy for Advanced Studies in America, Columbia University, USA \\ ${ }^{2}$ Centre for Conservation and Archaeology of Montenegro, Cetinje, Montenegro \\ ${ }^{3}$ Archaeological Collection, Faculty of Philosophy, University of Belgrade, Serbia \\ ${ }^{4}$ Laboratory for Bioarchaeology, Faculty of Philosophy, University of Belgrade, Serbia \\ ${ }^{5}$ Faculty of Humanities, Juraj Dobrila University of Pula, Croatia \\ ${ }^{6}$ Institute for Balkan Studies, Serbian Academy of Sciences and Arts, Belgrade, Serbia \\ ${ }^{7}$ Institute for Pre- and Protohistory, Kiel University, Kiel, Germany \\ ${ }^{8}$ Àrea de Prehistòria, Universitat Rovira i Virgili, Tarragona, Spain \\ ${ }^{9}$ IPHES, Institut Català de Paleoecologia Humana i Evolució Social, Tarragona, Spain \\ ${ }^{10}$ Centre for Culture and National Museum in Nikšic, Montenegro \\ ${ }^{11}$ DANTE, Diet and Ancient Technology Laboratory, La Sapienza University, Rome, \\ Italy
}

This article presents a summary of new evidence for the Mesolithic in the Dinaric Alps of Montenegro. The region is one of the best areas in south-eastern Europe to study Early Holocene foragers and the nature of the transition to Neolithic lifeways at the end of the seventh and the beginning of the sixth millennium cal $B C$ thanks to the existence of biodiverse landscapes and numerous karstic features. We argue that harpoons found at two different sites in this regional context represent a curated technology that has its roots in a local Mesolithic cultural tradition. The continued use of this standardized bunting tool kit in the Neolithic provides an important indication about the character of the Mesolithic-Neolithic transition. We also use this regional case study to address wider questions concerning the visibility and modes of Mesolithic occupation in south-eastern Europe as a whole.

Keywords: harpoons, Mesolithic-Neolithic transition, forager-farmer contact, Dinaric Alps, Montenegro, eastern Adriatic

\section{INTRODUCTION}

The geographical affordances of the territory of present-day Montenegro have a high potential for the study of early prehistory. The eastern Adriatic littoral must have been an important natural conduit for the dispersal of human groups along the coast while the hinterlands of the Dinaric Alps contain numerous karstic features, such as caves and rock shelters, which served as key repositories of regional occupational histories. Yet, 


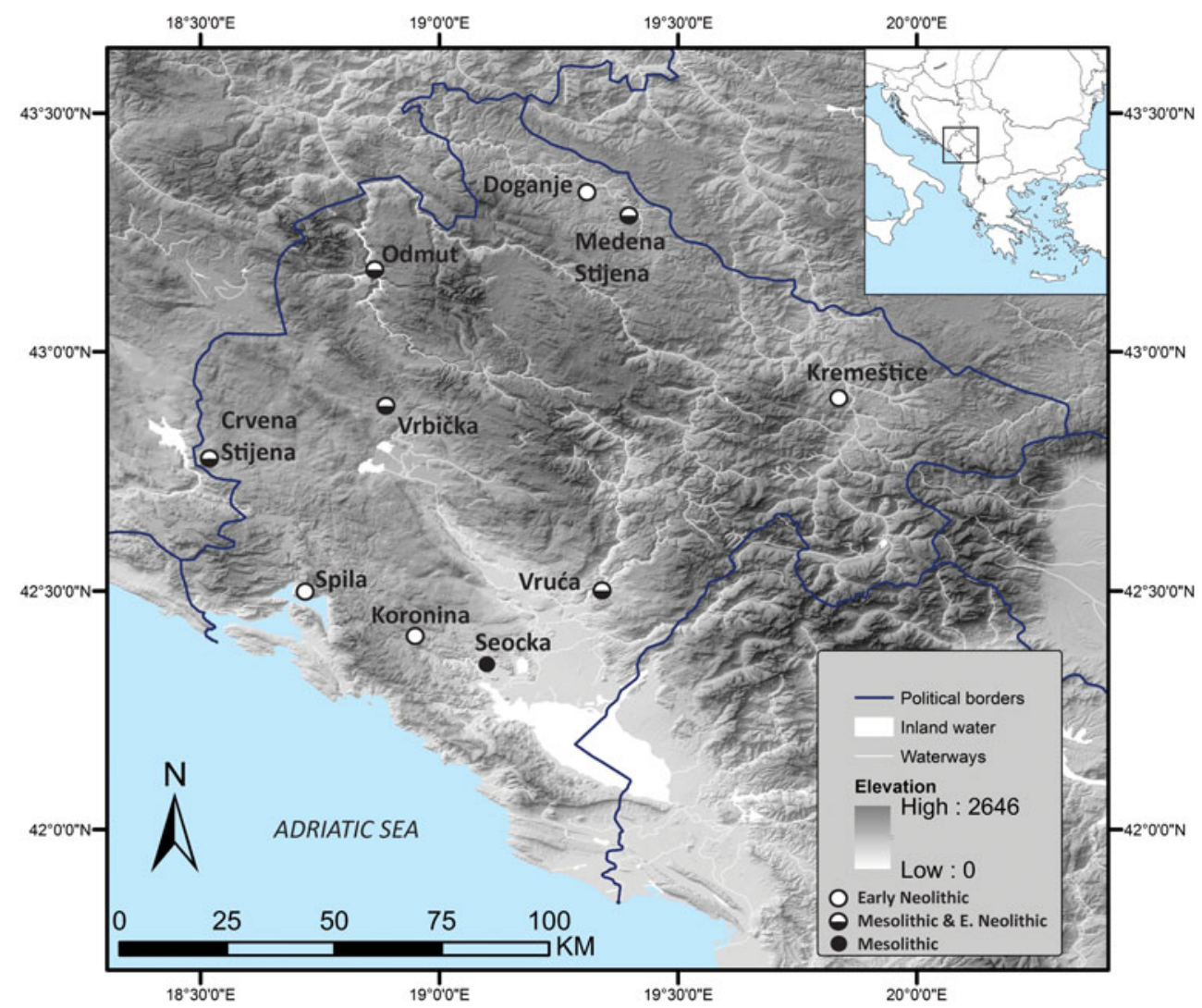

Figure 1. Map showing the position of known Mesolithic and Early Neolithic sites in Montenegro. Elevation data source: ASTER GDEM ('ASTER GDEM is a product of METI and NASA').

at present, there are only few known Mesolithic sites in Montenegro (Figure 1).

In this article, we examine the timing of the Mesolithic-Neolithic transition in the hinterland zone of the eastern Adriatic coast. Different strands of evidence from several sites are presented, the focus being on technological continuities in the manufacture and use of barbed points, i.e. harpoons, as a recognizable fossile directeur and part of a curated hunting toolkit with a high degree of standardization based on morphometric parameters. We also present some results of new fieldwork in this region, our techno-morphological and use-wear analysis of osseous and knapped stone artefacts, faunal datasets, and new direct AMS measurements on harpoons, other osseous artefacts, and environmental samples.

\section{Problems in Mesolithic Archaeologies of South-Eastern EUROPE}

With the exception of the Mesolithic sequences in the context of the Danube Gorges area (e.g. Bonsall, 2008; Borić, 2011, 2016 and references therein; Borić et al., 2014), the Mesolithic period in most of south-eastern Europe still remains patchy, with large blank areas in Greece (Galanidou, 2011), the eastern and central Balkans (Gurova \& Bonsall, 2014), and most of the Carpathian Basin (but for the latter region see Eichmann et al., 2010). The situation is somewhat better along the eastern Adriatic coast, where an abundance of karstic features such as caves and rock shelters contributed to Mesolithic 
deposits being identified more readily (e.g. Miracle, 1997; Miracle et al., 2000; Komšo, 2006; Mlekuž et al., 2008; Harrold et al., 2017; Hauck et al., 2017; Pilaar Birch \& Miracle, 2017). But sites with Mesolithic deposits, especially those dating to the seventh millennium cal $\mathrm{BC}$ (Forenbaher et al., 2013), are still few and far between, and a sustained focus on investigating this area as well as those blank spots on distribution maps elsewhere across the region is desperately needed.

It has been assumed that during the Last Glacial period, the Balkans acted as one of the southern European refugia for plant, animal, and human populations, with favourable environments especially during the Last Glacial Maximum (LGM) (e.g. Miracle, 2007; Magyari et al., 2013). Here, the transition from the Late Palaeolithic or Epipalaeolithic to the Mesolithic is not characterized by a radical break in the techno-morphological traditions of knapped stone industries. Across the Balkans there seems to be a pattern of continuing Epigravettian traditions with fewer diagnostic markers of temporal changes than in other parts of Europe (Kozłowski, 1999; see Galanidou, 2011: 232 for northern Greece). At the same time, the Holocene knapped stone industries from this region have also been characterized as markers of a 'decline' in comparison to the Late Upper Palaeolithic periods both in the type of raw materials used and in the range of manufactured tool types and techniques employed (Mihailović, 2001, 2007). While the concept of 'decline' might not be an optimal way to describe the change, it has been suggested that preferences in raw material choices with a shift towards locally available lithotypes (often with poorer knapping properties than those previously procured) may correspond to limited access to good-quality flint, and a decrease in the distances involved in the transfer of raw material may have been due to the spread of temperate deciduous woodland with densely forested environments across the region at the onset of the Holocene warming (Kozłowski \& Kozłowski, 1982; Willis, 1994).

In her review of the Mesolithic record in Greece, Galanidou (2011) suggested that rather than expecting a unifying picture and narrative of what Mesolithic groups were like, with some essential core of 'Mesolithicness', we should embrace a potential diversity of regional adaptations, 'more like a patchwork of patterns, colours and textures than a uniform design' (Galanidou, 2011: 231; see Borić, 2005). Galanidou also stresses that the frequent invisibility of Mesolithic sites may stem from a combination of factors that include our inability to differentiate diagnostic Mesolithic artefacts in those instances where these deviate from the expected norm (e.g. microliths and armatures, or the presence of a microburin technique), problems of taphonomy and palimpsest effects of timeaveraged thin deposits; these deposits may represent indistinguishable mixed episodes of ephemeral occupation where, in the absence of radiocarbon dates, the Mesolithic character of the occupation could easily go unnoticed. Our experience of working at Vrbička cave in Montenegro (see below), where targeted radiocarbon dating was instrumental in the identification of Mesolithic occupation deposits, makes us sympathetic to this predicament. Similarly, Mesolithic-age materials have been AMS-dated at the cave site of Seocka in Montenegro (Figure 1, Table 1) in mixed deposits belonging to later prehistoric occupation and testify to similar taphonomic difficulties in identifying Mesolithic remains (Vander Linden et al., 2014). 
Table 1. Mesolithic and Early Neolithic dates currently available from five Montenegrin sites. End points for calibrated dates and posterior density estimates are rounded up to ten years as the error terms are greater than twenty-five radiocarbon years.

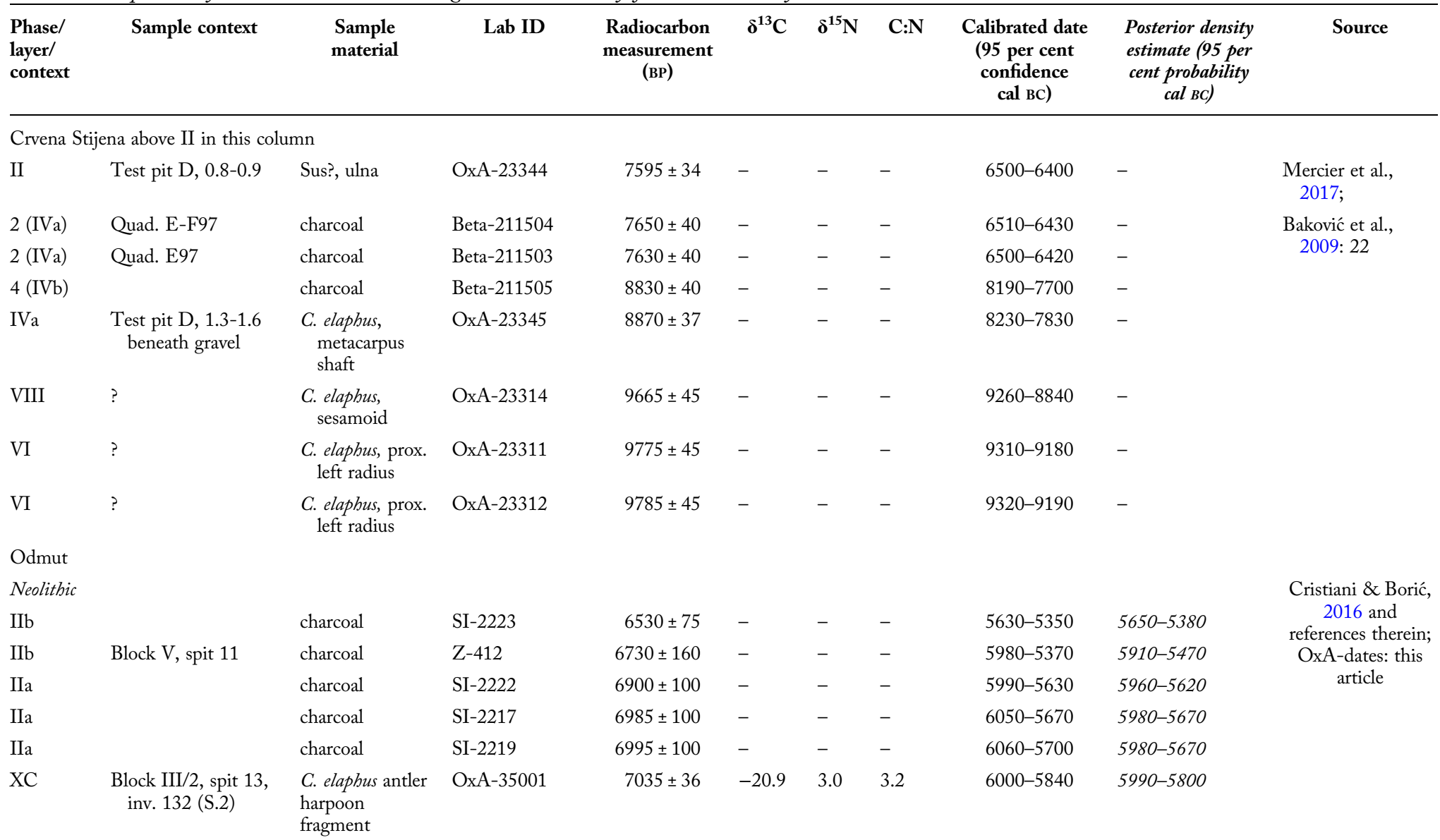


Table 1. (Cont.)

\begin{tabular}{|c|c|c|c|c|c|c|c|c|c|c|}
\hline $\begin{array}{l}\text { Phase/ } \\
\text { layer/ } \\
\text { context }\end{array}$ & Sample context & $\begin{array}{c}\text { Sample } \\
\text { material }\end{array}$ & Lab ID & $\begin{array}{c}\text { Radiocarbon } \\
\text { measurement } \\
\text { (BP) }\end{array}$ & $\delta^{13} \mathrm{C}$ & $\delta^{15} \mathrm{~N}$ & C:N & $\begin{array}{l}\text { Calibrated date } \\
\text { ( } 95 \text { per cent } \\
\text { confidence } \\
\text { cal } \mathrm{BC})\end{array}$ & $\begin{array}{c}\text { Posterior density } \\
\text { estimate ( } 95 \text { per } \\
\text { cent probability } \\
\text { cal BC) }\end{array}$ & Source \\
\hline \multicolumn{11}{|c|}{ Mesolithic } \\
\hline $\mathrm{Ib}$ & Block I, spit 19 & charcoal & $Z-457$ & $7030 \pm 160$ & - & - & - & $6230-5630$ & $6340-5880$ & \\
\hline $\mathrm{Ib}$ & & charcoal & SI-2227 & $7080 \pm 85$ & - & - & - & $6100-5740$ & $6210-5890$ & \\
\hline $\mathrm{Ib}$ & & charcoal & SI-2220 & $7150 \pm 100$ & - & - & - & $6240-5810$ & $6230-5910$ & \\
\hline Ia & Block V, spit 21 & charcoal & Z-413 & $7350 \pm 160$ & - & - & - & $6510-5900$ & $6500-5970$ & \\
\hline $\mathrm{Ib}$ & Block V, spit 15 & charcoal & $Z-411$ & $7440 \pm 150$ & - & - & - & $6590-5950$ & $6590-6020$ & \\
\hline $\mathrm{XA}$ & Block IV/2, spit 11 & $\begin{array}{l}\text { C. elaphus antler } \\
\text { harpoon } \\
\text { fragment }\end{array}$ & OxA-32283 & $7757 \pm 38$ & -20.23 & 3.2 & 3.4 & $6650-6480$ & $6650-6480$ & \\
\hline $\mathrm{Ib}$ & & charcoal & SI-2221 & $7720 \pm 85$ & - & - & - & $6770-6410$ & $6760-6410$ & \\
\hline $\mathrm{Ia}$ & $\begin{array}{l}\text { Block V, spit 16, } \\
\text { inv. } 476(\mathrm{~S} .4)\end{array}$ & $\begin{array}{l}\text { C. elaphus antler } \\
\text { harpoon } \\
\text { fragment }\end{array}$ & OxA-35003 & $7770 \pm 40$ & -20.5 & 2.6 & 3.2 & $6680-6490$ & $6680-6490$ & \\
\hline $\mathrm{Ib}$ & & charcoal & SI-2226 & $7790 \pm 70$ & - & - & - & $6910-6460$ & $6910-6460$ & \\
\hline $\mathrm{Ib}$ & $\begin{array}{l}\text { Block II, spit 18, } \\
\text { inv. } 199 \text { (S.1) }\end{array}$ & $\begin{array}{l}\text { C. elaphus antler } \\
\text { harpoon } \\
\text { fragment }\end{array}$ & OxA-34966 & $7980 \pm 50$ & -21.3 & 3.1 & 3.2 & $7060-6700$ & $7060-6700$ & \\
\hline$?$ & $\begin{array}{l}\text { Block IV/1, spit 13, } \\
\text { inv. } 394 \text { (S.3) }\end{array}$ & $\begin{array}{l}\text { C. elaphus antler } \\
\text { harpoon } \\
\text { fragment }\end{array}$ & OxA-35002 & $8207 \pm 39$ & -20.3 & 2.7 & 3.2 & $7340-7080$ & $7340-7080$ & \\
\hline $\mathrm{Ia} / \mathrm{Ib}$ & $\begin{array}{l}\text { 'Mixed dark and } \\
\text { yellow sediment' }\end{array}$ & charcoal & SI-2224 & $8590 \pm 100$ & - & - & - & $7960-7460$ & $7960-7460$ & \\
\hline $\mathrm{Ib}$ & & charcoal & SI-2228 & $9135 \pm 80$ & - & - & - & $8570-8230$ & $8560-8000$ & \\
\hline $\mathrm{XD}$ & Block III/1, spit 17 & charcoal & SI-2225 & $10045 \pm 85$ & - & - & - & 10020-9310 & $9980-9290$ & \\
\hline \multicolumn{11}{|c|}{ Vrbička cave } \\
\hline (29) & $\begin{array}{l}\text { Tr. } 1 / 2013 \text {, spit } 5 \text {, } \\
\quad \text { quad. } 103 / 102 / \mathrm{C}\end{array}$ & $\begin{array}{l}\text { Corylus avellana } \\
\text { charred } \\
\text { nutshell }\end{array}$ & OxA-32862 & $7923 \pm 39$ & -24.29 & - & - & $7030-6660$ & - & This article \\
\hline
\end{tabular}




\begin{tabular}{|c|c|c|c|c|c|c|c|c|c|c|}
\hline (16) & $\begin{array}{l}\text { Tr. 1/2012, spit } 4 \text {, } \\
\quad \text { quad. } 100 / 100 / D \\
\text { (bag } 564,13 / 08 / \\
\text { 2012) }\end{array}$ & $\begin{array}{l}\text { S. scrofa tusk } \\
\text { tool }\end{array}$ & OxA-27790 & $8040 \pm 34$ & -20.05 & 6.5 & 3.3 & $7080-6820$ & - & This article \\
\hline \multicolumn{11}{|l|}{ Vruća cave } \\
\hline 10YR $4 / 2$ & $\begin{array}{l}\text { Quad. A5/2, spit 8, } \\
\text { bag } 122 \text { (29/11/ } \\
\text { 1988) }\end{array}$ & $\begin{array}{l}\text { C. elaphus antler } \\
\text { harpoon }\end{array}$ & OxA-32282 & $6902+35$ & -19.91 & 2.4 & 3.2 & $5880-5710$ & - & This article \\
\hline 10YR 2/2 & $\begin{array}{l}\text { Quad. B4/2, spit 9, } \\
\text { bag 202 (01/12/ } \\
\text { 1988) }\end{array}$ & $\begin{array}{l}\text { C. elaphus antler } \\
\text { harpoon }\end{array}$ & OxA-28274 & $6969+33$ & -19.51 & 1.3 & 3.3 & $5980-5750$ & - & This article \\
\hline $10 \mathrm{YR} 4 / 4$ & $\begin{array}{l}\text { Quad. B4/4, spit 21, } \\
\text { inv. VR-40/97-1 } \\
(15 / 11 / 1997)\end{array}$ & $\begin{array}{l}\text { bone tool, } \\
\text { medium-sized } \\
\text { mammal }\end{array}$ & OxA-31133 & $8200 \pm 45$ & -22.04 & 3.3 & 3.2 & $7340-7070$ & - & This article \\
\hline \multicolumn{11}{|c|}{ Seocka cave } \\
\hline 1006 & $\begin{array}{l}\text { Tr. 1, Quad. L22, } \\
\text { spit } 5\end{array}$ & C. capreolus & SUERC-50661 & $8778 \pm 35$ & - & - & - & $7970-7670$ & - & $\begin{array}{l}\text { Vander Linden } \\
\text { et al., } 2014\end{array}$ \\
\hline \multirow[t]{3}{*}{1006} & $\begin{array}{l}\text { Tr. 1, Quad. L22, } \\
\text { spit } 5\end{array}$ & R. rupicapra & SUERC-50662 & $8823 \pm 34$ & - & - & - & $8200-7750$ & - & \\
\hline & $\begin{array}{l}\text { Tr. 2, Quad. M29a, } \\
\text { spit } 7\end{array}$ & C. capreolus & SUERC-50660 & $8903 \pm 34$ & - & - & - & $8230-7960$ & - & \\
\hline & $\begin{array}{l}\text { Tr. 2, Quad. M29a, } \\
\text { spit } 7\end{array}$ & C. capreolus & SUERC-50656 & $9311 \pm 55$ & - & - & - & $8720-8340$ & - & \\
\hline
\end{tabular}


This recognition of the difficulties attached to discovering Mesolithic-age deposits stands in contrast to a recent suggestion by Gurova \& Bonsall (2014), that the invisibility of Mesolithic occupation across south-eastern Europe should be taken at face value, as evidence that large tracts of land under a dense canopy cover remained uninhabited during the Mesolithic due to a concomitant reduction in ungulate biomass. They further suggest that concentrations of sites are to be expected only along riparian corridors, in wetland inland areas rich in aquatic resources and along coasts, with largely unoccupied hinterlands (see also Pilaar Birch \& Vander Linden, 2018: 185). While tackling this model on empirical grounds for the whole of the region remains outside the remits of this article, our presentation of the Mesolithic evidence from Montenegro may contribute to a further contextualization of the problem of Mesolithic invisibility in south-eastern Europe, to which we will return in our discussion.

\section{The Mesolithic of Montenegro}

There are currently only six sites (caves and rock shelters) with Mesolithic occupation deposits in Montenegro (Figure 1). Currently no open-air sites dated to the Mesolithic are known. Here, we present the results of our recent work on extant collections from the Odmut rock shelter and Vruća cave and our fieldwork at the newly discovered site of Vrbička cave in an attempt to further our understanding of these sites' Mesolithic occupation and to answer the question concerning the transition to the Neolithic in this regional context. The evidence from three other Mesolithic sites-Crvena Stijena, Medena Stijena (Mihailović, 1996), and Seocka cave-will contribute to our later discussion of wider regional patterns.

\section{Odmut}

In 1972-1974, rescue excavations at the

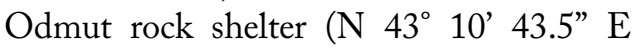
$18^{\circ} 51^{\prime} 13.3$ ”, c. $558 \mathrm{~m}$ asl; Figure 2) produced the first extensive and dated sequence of Mesolithic occupation in Montenegro (Marković, 1974; Srejović, 1974), complementing at the time already known Mesolithic finds from the Crvena Stijena rock shelter (see Basler, 1975; Baković et al., 2009; Mihailović, 2009; papers in Whallon, 2017) (Figure 1). The site is located $85 \mathrm{~km}$ inland from the coast of the Adriatic Sea, above the river Vrbnica before its confluence with the river Piva. A stratified sequence $4 \mathrm{~m}$ deep was uncovered (Figure 3), ranging from the Early Mesolithic to the Bronze Age. More than half the stratigraphic sequence spans the Early to Late Mesolithic (phases/layers $\mathrm{XD}, \mathrm{XA}, \mathrm{Ia}$, and Ib) and Early Neolithic (phases/layers IIa, IIb, XB, and XC). Two of us have published a more detailed account of various features from this site and its stratigraphy elsewhere (Cristiani \& Borić, 2016).

Table 1 lists all available radiocarbon dates from Odmut, including four new AMS dates reported here for the first time. Five AMS measurements directly date diagnostic single-barbed points made on red deer antler found in different Mesolithic and Early Neolithic deposits. They help us understand the origin and duration of the curated and standardized technological tradition of completely shaped unilateral harpoons with straight barbs and single or double mesial, distal, and/or proximal perforation(s) (Figure 4). In the article that first described harpoons from Odmut, Srejović (1974) mentions fifty-six specimens. It was possible to locate and study twenty-nine exemplars (Cristiani \& Borić, 2016). These harpoons were found in both Mesolithic $(n=19)$ and Neolithic levels $(n=7)$. After Bayesian 


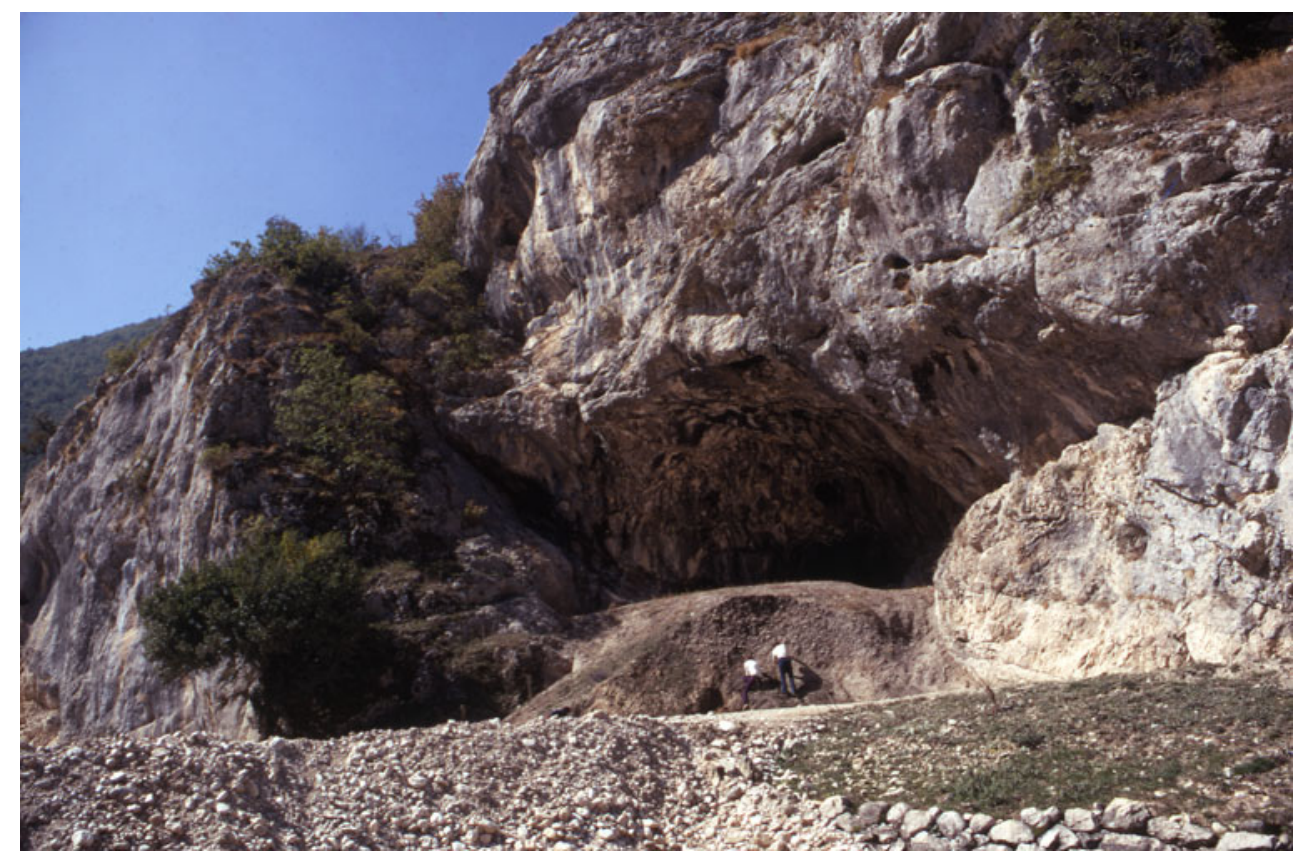

Figure 2. View of the Odmut rockshelter at the start of excavations in 1972.

Photograph by kind permission of Alan McPherron.

modelling of all available dates from Odmut (agreement index $A_{\text {overall }}=98.3$; Figure 5; see also Supplementary Material 1), the oldest AMS-dated unilateral harpoon (OxA-35002) with two barbs and one mesial perforation gives the range of 7340-7080 cal BC (95 per cent probability). This measurement suggests that the beginnings of this tool tradition can probably be ascribed to at least the start of the regional Late Mesolithic. There are also three measurements (OxA-32283, OxA34966, and OxA-35003) that date another three fragmented harpoons from Odmut to the beginnings and the middle of the seventh millennium $\mathrm{BC}$, thus partly overlapping with the charcoal dates available for Mesolithic layers Ia and Ib (Table 1, Figure 5). Finally, OxA-35001, which dates a harpoon fragment from the Early Neolithic layer XC (see Figure 3), is consistent with its Early Neolithic attribution and provides the youngest direct date yet for a harpoon from this site, which calibrates to 5990-5800 cal BC (95 per cent probability).

At face value, these results suggest that the use of harpoons at Odmut spanned a millennium or more, throughout the Late Mesolithic and into the Early Neolithic, during which time ceramics made their appearance at the site, chronologically overlapping with the appearance of Early Neolithic sites elsewhere in the Balkans. Further, existing faunal data (Cristiani \& Borić, 2016: 174, table 2) from Odmut show that the most hunted species in the Mesolithic occupation phase Ia (NISP = 1232, excluding bird and fish remains) is ibex (58 per cent), followed by red deer (20.5 per cent), marten (4.9 per cent), wild boar (3.8 per cent), chamois (3.2 per cent), and several other species found in smaller quantities. Similar frequencies of hunted species are reported for phase Ib (NISP $=668$, excluding birds and fish 


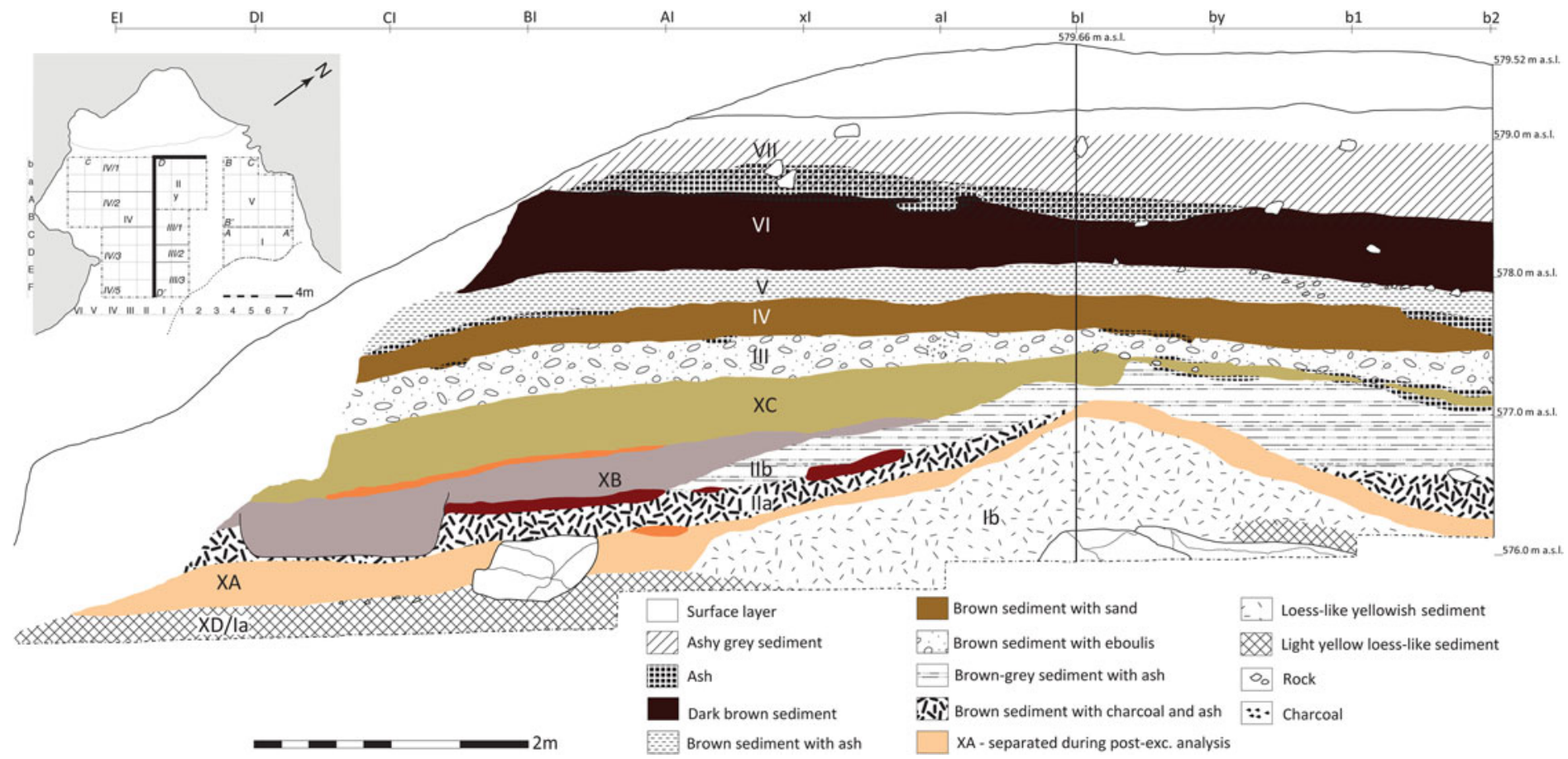

Figure 3. Stratigraphy of Odmut as shown on section $D-D$ '.

Retraced and adapted after Koztowski et al. (1994: fig. 2) by D. Boric. 


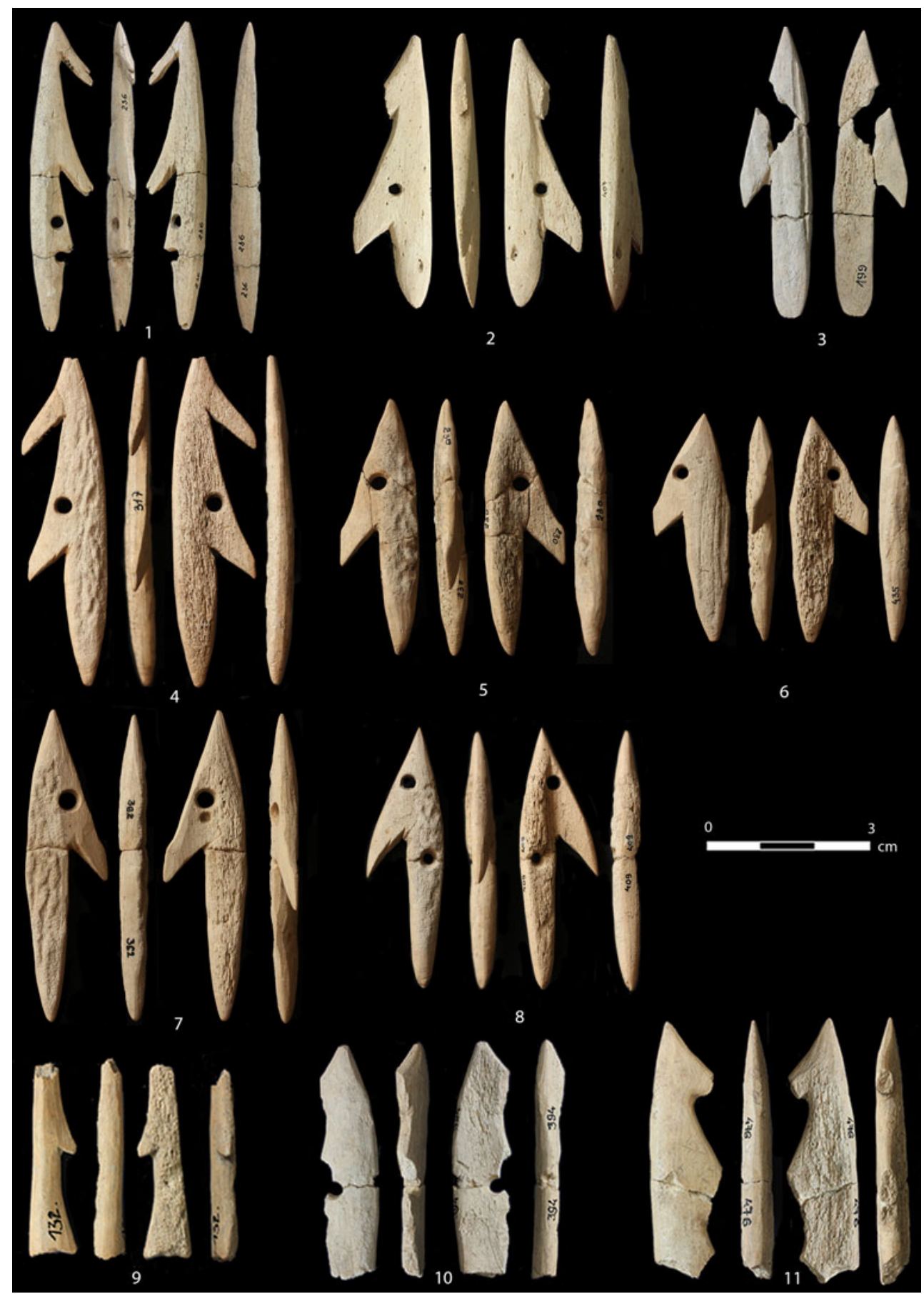

Figure 4. A selection of complete and fragmentary barbed points found in different Mesolithic and Early Neolithic layers at Odmut, including four AMS-dated specimens. 1: Layer IIa; 2: Layer Ia; 3: Layer Ib, OxA-34966; 4-8: Mesolithic levels; 9: Layer XC, OxA-35001; 10: Mesolithic levels, OxA35002; 11: Layer Ia, OxA-35003 (see Table 1).

Photographs by D. Boric and E. Cristiani. 


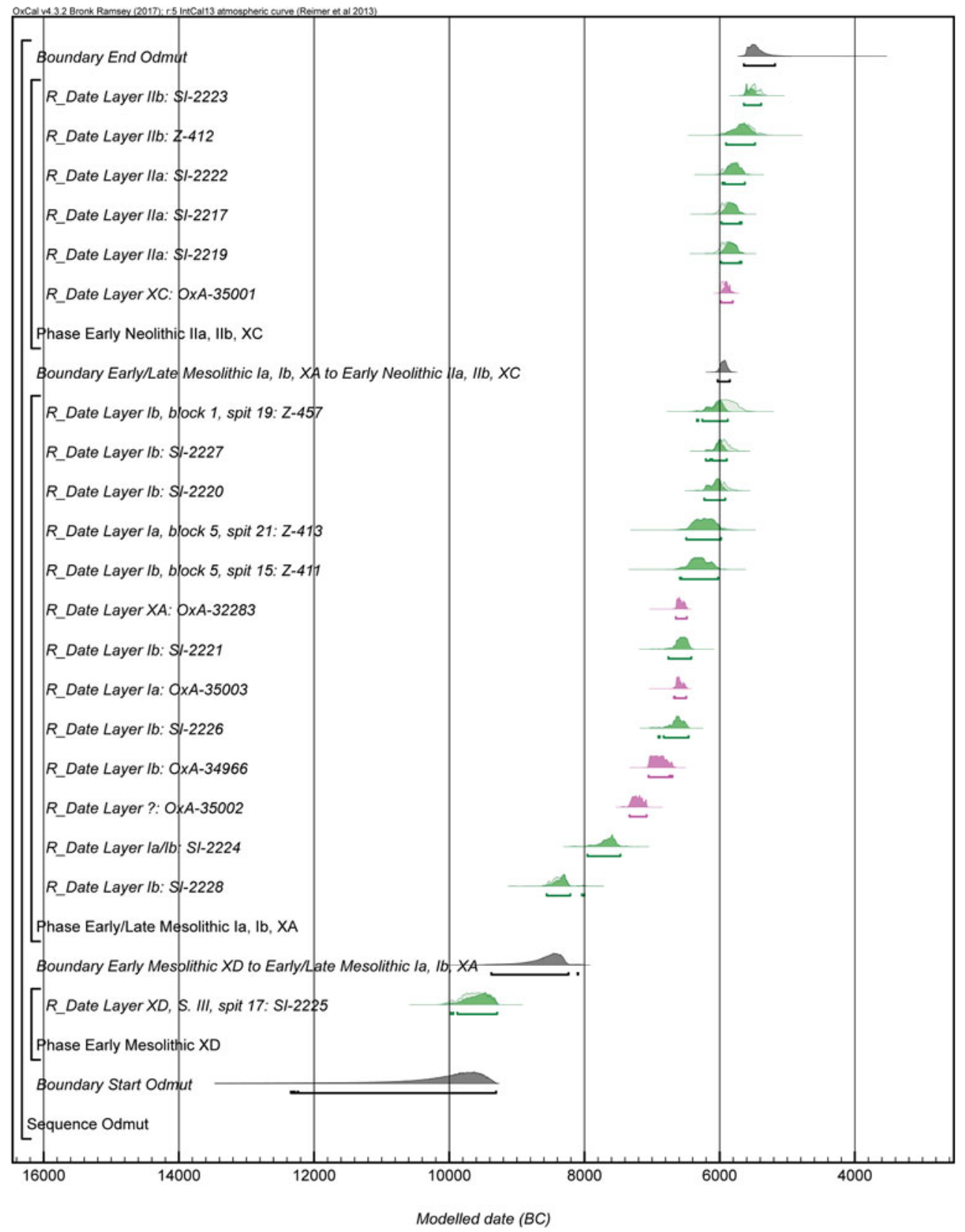

Figure 5. Probability distributions of radiocarbon measurements from Odmut. Each distribution represents the relative probability that an event occurred at a particular time. For the radiocarbon measurements, distributions in outline are the results of simple radiocarbon calibrations, solid distributions are the output from the chronological model. Dates are calibrated using OxCal v4.3.2 (Bronk Ramsey $E^{\circ}$ Lee, 2013). Green: charcoal dates; magenta: antler AMS dates. The CQL code can be found in Supplementary Material 1. 
remains) where again ibex dominates (59.5 per cent), followed by red deer (14.1 per cent), chamois (10.2 per cent), marten (9.3 per cent), wild boar (2.5 per cent), and several other species found in smaller quantities. Seven specimens of domestic cattle are also reported for phase Ib and, like the ceramics found in this layer, these could be intrusive. While in Early Neolithic phases IIa-IIb $(\mathrm{NISP}=324)$ small quantities of domestic animals, such as sheep/goat (9.6 per cent), cattle (4.3 per cent), and pig ( 0.6 per cent), have been found, the majority of animal protein still came from red deer (41.4 per cent), ibex (34 per cent), and chamois (3.1 per cent). This would suggest that not much changed in subsistence patterns from the Mesolithic to the Neolithic even though no fish remains are reported in Early Neolithic levels. Assuming that harpoons were primarily used for fishing, the absence of fish remains, if not caused by a recovery bias, contradicts the harpoons' continued presence at the site in the Neolithic, and may imply that they continued to be manufactured as part of the preceding Mesolithic cultural tradition. It is also possible that barbed points were used for (aquatic) mammal hunting as attested in various ethnographic examples (e.g. Pétillon, 2008).

As for the chipped stone industry, while there are some oscillations over time in the presence of certain techno-morphological categories and in the choice of raw materials, there are continuities in the structure of the assemblage throughout the Mesolithic and into the Early Neolithic with a tendency over time for increasingly laminar knapped stone industries with armatures in the form of trapezes and micro-retouched bladelets (Kozłowski et al., 1994; cf. Cristiani \& Borić, 2016: 171-72). This change is pronounced in layers Ib and particularly XA. The percentage of non-local lithotypes with good knapping properties also increases during phase XA. The important novelty among retouched blades in layer XA are specimens with two opposite notches, which are characteristic of Castelnovian industries in Italy (Mihailović, 2009: 102-04; Franco, 2011). At Odmut, these pieces were also found in the Neolithic layer IIa but they disappear in layers IIb and $\mathrm{XC}$, with blades dominating in a very small lithic assemblage from layer $\mathrm{XC}$. The important difference between Montenegrin and other Balkan Mesolithic sites on the one hand, and the 'classic' Castelnovian core area in northern Italy on the other, relates to the absence of the microburin technique in the production of trapezes as well as the lack of asymmetrical trapeze shapes and rhombs in the former regions (Kozłowski et al., 1994: 67).

In sum, at Odmut, some Neolithic novelties, such as ceramics, a small number of domesticates, and also the acquisition of good-quality non-local lithotypes, were introduced at the time of the MesolithicNeolithic transition currently estimated to have occurred around 6040-5850 cal BC (95 per cent probability), probably in 5990$5890 \mathrm{cal}$ BC (68 per cent probability) (Early/ Late Mesolithic Ia, Ib, XA to Early Neolitbic IIa, IIb, XC boundary). However, we have established continuities in the use of harpoons and in the character of the knapped stone assemblages throughout the Late Mesolithic (phases Ia, Ib, and XA) and into the earliest Neolithic (phases XC and IIa) occupation of the site along with evidence for a continuous dominance of hunted game in the Early Neolithic subsistence.

\section{Vruća cave}

Vruća cave (N 42 30'31.93”, E $19^{\circ} 19^{\prime}$ 3.97 ", c. $124 \mathrm{~m}$ asl; Figure 1) is situated near the village of Bioče, $45 \mathrm{~km}$ inland from the nearest coast of the Adriatic Sea. 
The cave is located high towards the top of the limestone massif on the left side of the Mala Rijeka tributary in the vicinity of its confluence with the larger river Morača, well-known for its dramatic, deeply carved canyon. The site was investigated in 1988-1989 and 1996-1997 (Đuričić, 1997). It is a small tunnelshaped cave $11 \mathrm{~m}$ long and 3-4 m wide, with a $4.5 \mathrm{~m}$ wide and $3.5 \mathrm{~m}$ high entrance; it has a southern exposure with a $5 \times 3 \mathrm{~m}$ terrace in front of the cave. The excavated area covered a surface of $7 \times 2 \mathrm{~m}$ (Figure 6; see also Supplementary Material 1) and the stratigraphic sequence is up to $1.5 \mathrm{~m}$ thick. Medieval and later prehistoric ceramics were found in surface levels (10YR 3/1, 10YR 5/3, 10YR 3/2; all layers are marked with Munsell colour chart designations).

The Mesolithic layer (10YR 4/4) contains lenses of charcoal and ash (10YR 3/6, 10YR 7/2). In the part of quadrant $A / 3-4$, at the top of the Mesolithic levels, there is a hearth with hardened sediment around it that spreads into the unexcavated section. Compared to later levels, there are fewer animal bones but numerous snail shells. Red deer, roe deer, and ibex are the dominant hunted species along with a number of fish remains and pond tortoise carapaces (see Supplementary Material 2). One burnt marine gastropod, Columbella rustica, was found at the top of the Mesolithic layer (spit 12) (Boric \& Cristiani, 2016: fig. 11.5). An asymmetrical pointed tool found in spit 21 (Supplementary Figure 3.8) was dated (OxA-31133) to 7340-7070 cal BC (95 per cent confidence) (Table 1). In the Mesolithic assemblage of knapped stone tools, retouched tools were frequently made on narrow bladelets $(<12 \mathrm{~mm})$. Among retouched tools are scrapers, end scrapers and thumbnail scrapers, notched tools, truncations, burins, borers, as well as geometric microliths of trapezoid and triangular types (Đuričić, 1997). Only one harpoon was found in the presumably Mesolithic levels in spit 16 (Figure 7.5).

The Neolithic layer (10YR 4/3) had several lenses of charcoal and ash (10YR 2/2, 10YR 5/2, 10YR 4/2). It contained ten fragments of Impressed Ware (Đuričić, 1997) and numerous animal bones dominated by cervids (red deer and roe deer), knapped stone tools, harpoons, and other bone artefacts (Supplementary Material 1). However, apart from osseous tools, we have not been able to study the faunal assemblage from the Neolithic levels. Among the chipped stone tools, blades and bladelets dominate with many narrow blades (width $<12 \mathrm{~mm}$ ), followed by scrapers, tools with unilateral or opposite double notches, truncations, backed tools and composite tools, including backed tools with notches on narrow blades and a combination of burin and notching (Supplementary Figure 4). There were fifteen whole or fragmented unilateral barbed points in this layer (Figure 7; see also Supplementary Material) and on techno-morphological grounds these are part of the same tradition as those found at Odmut (see below). The presence of a manufacturing phase on a harpoon roughout (Figure 7.11) points to local production. This roughout (spit 9) and another fragmented harpoon with a perforation (spit 8) have directly been AMS-dated and their calibrated ranges largely overlap: 5980-5750 and 59005710 cal BC (95 per cent confidence) respectively (Table 1 ), thus confirming their expected Early Neolithic date.

In sum, the regional Mesolithic tradition of using harpoons is attested primarily in the Early Neolithic and only minor changes were observed in the character of the flint assemblages at Vruca between the two periods. The question of chronological continuity between the Mesolithic and Neolithic levels must be resolved by further radiocarbon dating. 


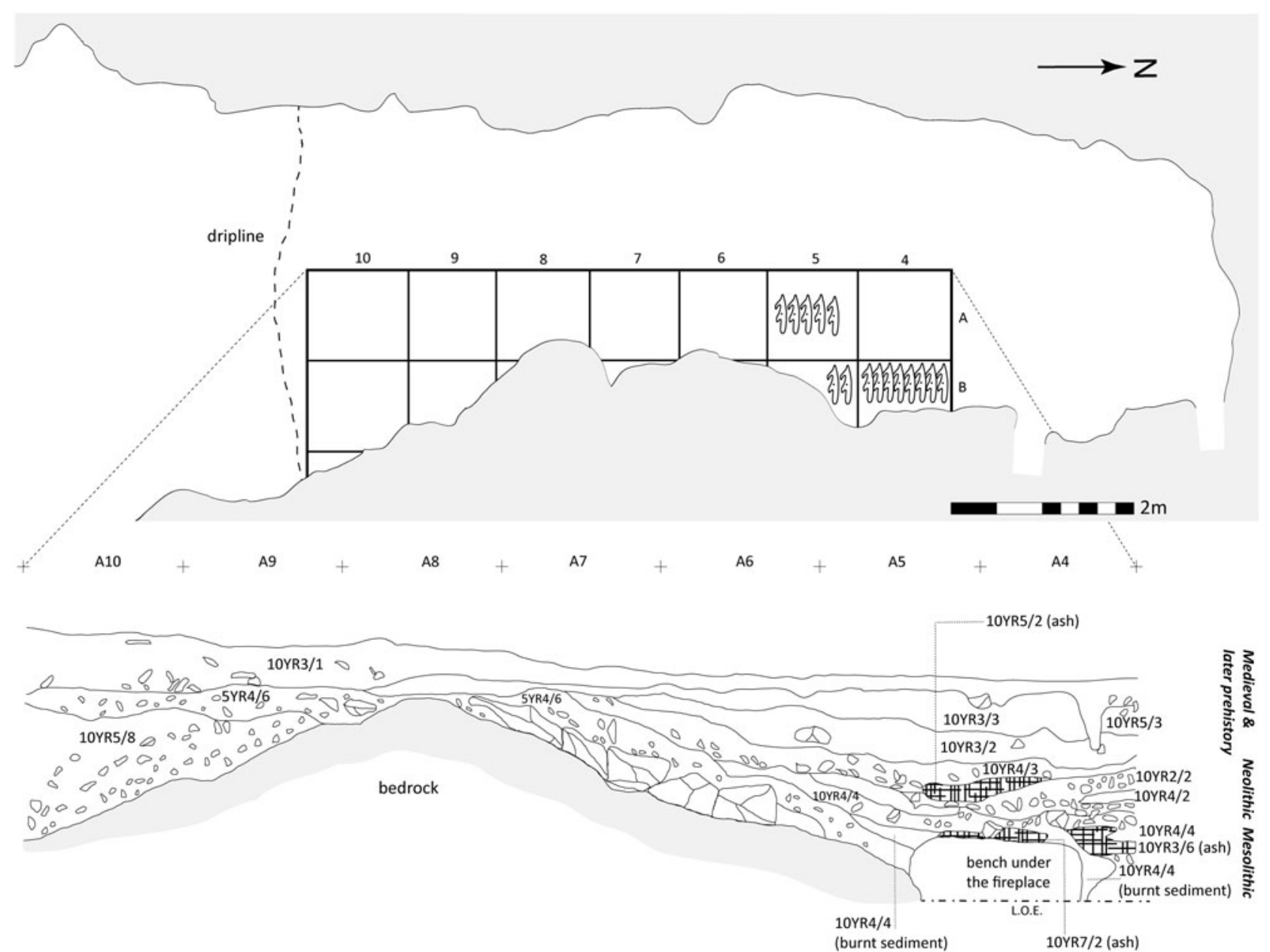
Retraced and adapted by D. Boric. 


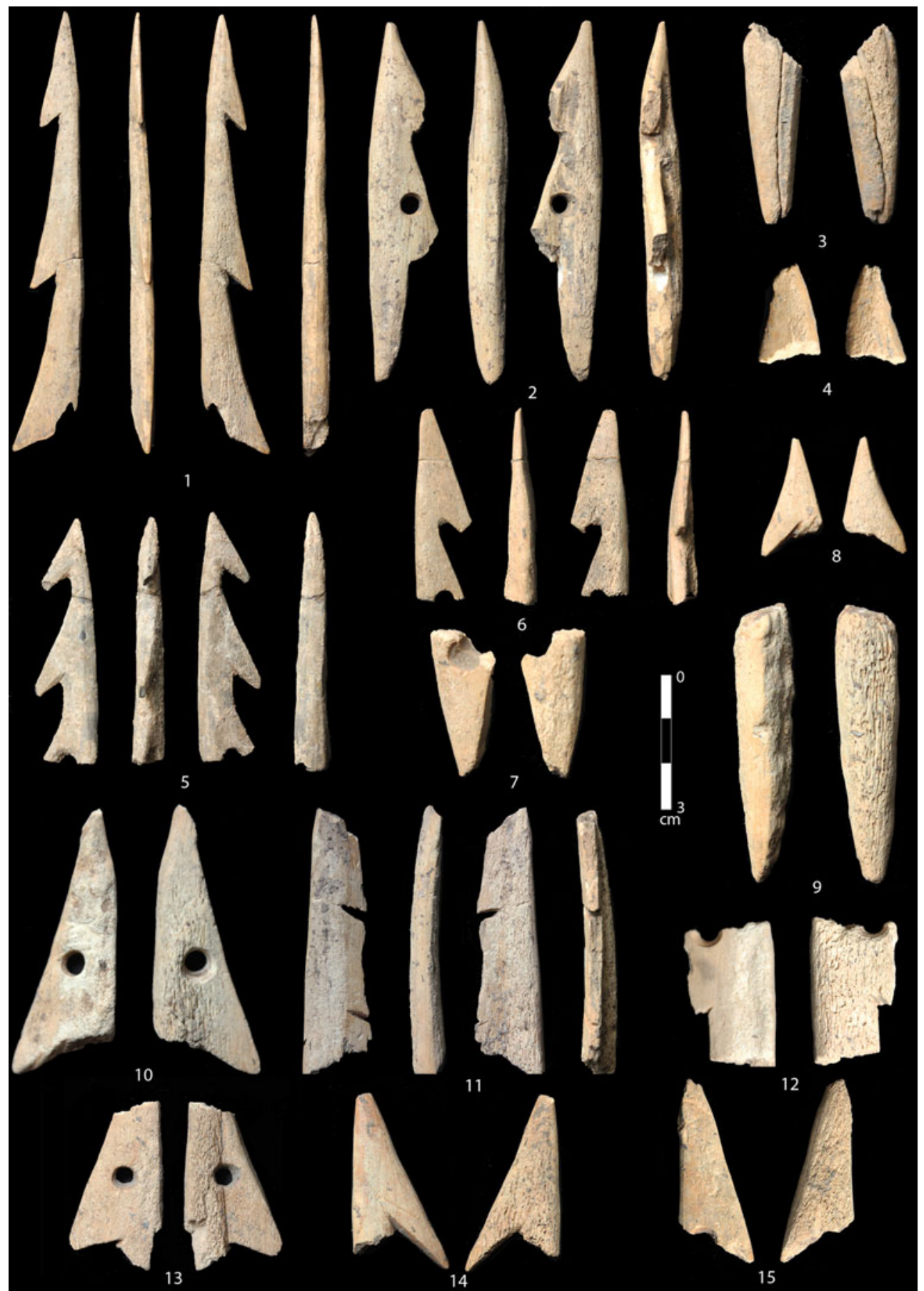

Figure 7. Barbed points found in Vruica cave. 11: OxA-28274; 14: OxA-32282. Photographs by E. Cristiani. 


\section{Vrbička cave}

Vrbička cave (N $42^{\circ} 53^{\prime} 27.2^{\prime \prime}$, E $18^{\circ} 52^{\prime}$ 14.3 ", c. $948 \mathrm{~m}$ asl; Figure 1) overlooks the Duga ravine in the village of Presjeka, at a distance of c. $18 \mathrm{~km}$ north-west of the present-day town of Nikšic, $60 \mathrm{~km}$ inland from the nearest coast of the Adriatic Sea. The cave is located on a limestone escarpment with commanding views of the surrounding landscape (Figure 8A) and with good-quality, permanent freshwater springs nearby. Our excavations at the site took place in 2012-2013 and 2015-2017. The site contains finds dated to the Upper Palaeolithic, Mesolithic, Early Neolithic, Late Neolithic, Copper Age, and Bronze Age. The Mesolithic layer (Figure 8B) lies on top of an erosion surface, at the interface between Late Pleistocene and Holocene sediments. The fine fraction of this unit is characterized by a very loose, homogeneous, dark grey silt matrix, while the coarse fraction consists of a mix of very frequent angular to subangular limestone clasts $(\sim 1$ $\mathrm{cm}$ being the most common) and charcoal (for a detailed micromorphological description, see Supplementary Material 1). It is only c. $10 \mathrm{~cm}$ thick and, in some areas of the excavated surface (Figure 9), the layer was removed by later prehistoric intrusions.

The Mesolithic knapped stone assemblage is characterized by local flints, some of poor knapping properties. Among formal tools, very small thumbnail end scrapers appear as the most characteristic artefact within this assemblage along with blades, bladelets, and prismatic cores for very narrow bladelets (Figure 10). The faunal remains are dominated by roe deer, red deer, ibex, wild boar, and chamois (see Supplementary Material 2). The absence of fish remains is not surprising considering the cave's environmental setting. Harpoons are absent. The Mesolithic occupation at Vrbička is dated to the very end of the eighth millennium or the first three centuries of the seventh millennium cal $\mathrm{BC}$ by two broadly contemporaneous AMS dates (Table 1): OxA-27790 dates a wild boar tusk tool to 7080-6820 cal BC (at 95 per cent confidence) (Figure 10.1); OxA32862 dates a hazelnut shell to $7030-6660$ cal BC (at 95 per cent confidence). Currently in Montenegro, systematic flotation of excavated sediments has only been undertaken at Vrbička. Preliminary results from the Mesolithic context/layer (29) excavated in 2013 show the presence of burnt shells of hazelnut (Corylus avellana) as well as vitrified fragments of their kernels, that is the edible part of the nut. An unexpected discovery was a perforated bead made from a Rutilus sp. (carp family) pharyngeal tooth found in the Mesolithic context (29) (Figure 10.2). Similar beads have been found in large numbers in Late Mesolithic burials of the Danube Gorges area (Cristiani \& Borić, 2012; Borić et al., 2014) and it is very likely that, if not the bead itself, the ornamental tradition of using such beads originated in the Danube Gorges area, more than $300 \mathrm{~km}$ away from Vrbička cave. Columbella rustica beads have also been found at Vrbička (Figure 10.3-4).

There were also a number of Early Neolithic decorated Impressed Ware sherds (Figure 10.11-14) found as part of the palimpsest in the levels above the Mesolithic sediments. At present, these Early Neolithic visitations of the cave remain undated. It is likely that there is a considerable hiatus in the occupation of the cave between the Late Mesolithic and the Early Neolithic.

\section{Discussion}

\section{Harpoons as a fossile directeur of a cultural tradition}

Based on our techno-morphological examination of barbed points from Odmut and Vruća cave, we suggest that these 


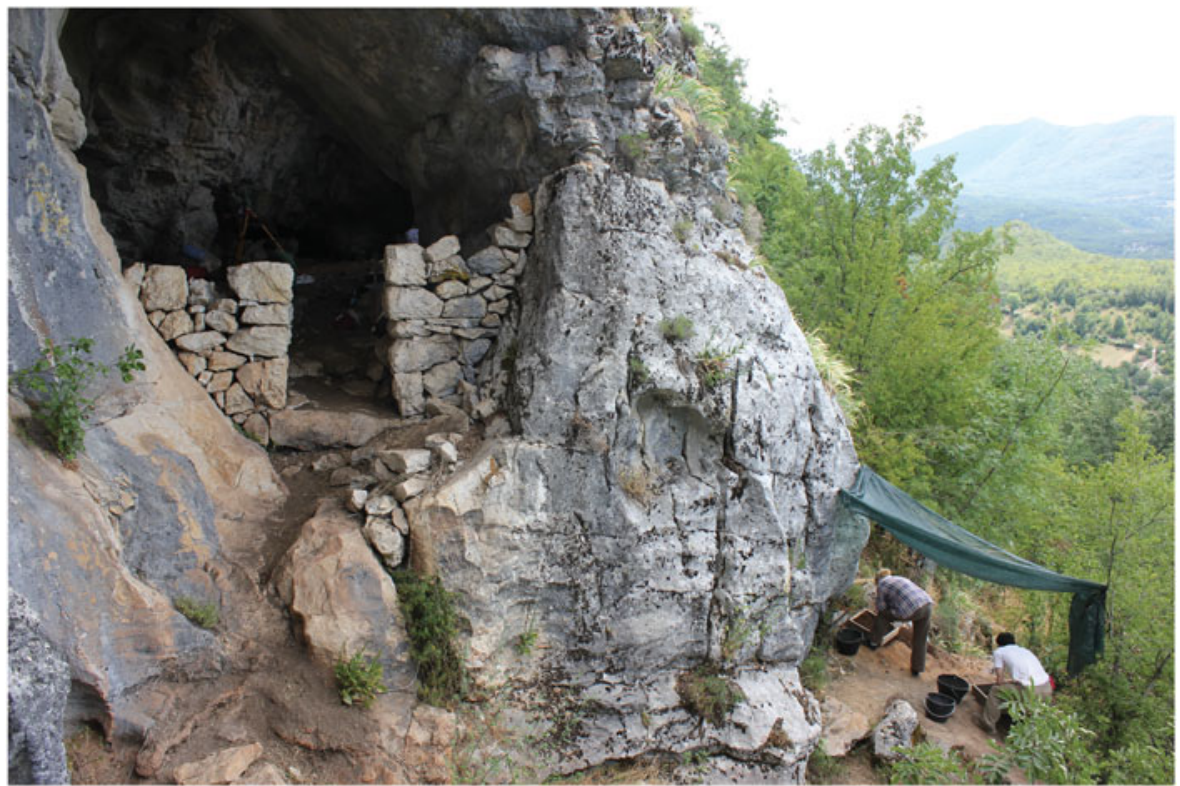

A

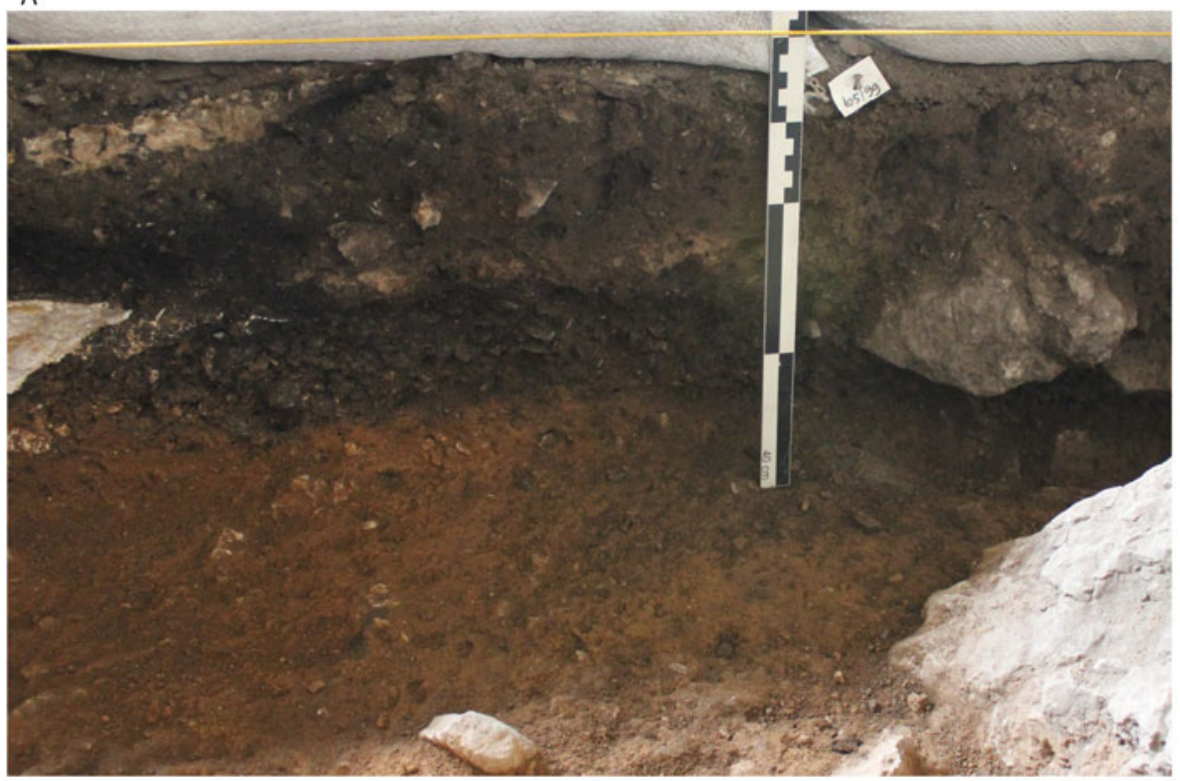

B

Figure 8. A: View of Vrbicka cave in August 2012. B: Stratigraphy as seen on the east-facing section in Trench 1/2013 with the Mesolithic layer context (29) directly above the reddish Late Pleistocene sediments.

Photographs by D. Boric.

specimens in the Montenegrin regional context share a common tradition of techno-functional gestures and know-how involved in their production and use. The analysed specimens can be described as completely shaped unilateral harpoons with straight barb(s) and single or double mesial, distal, and/or proximal perforation(s) 


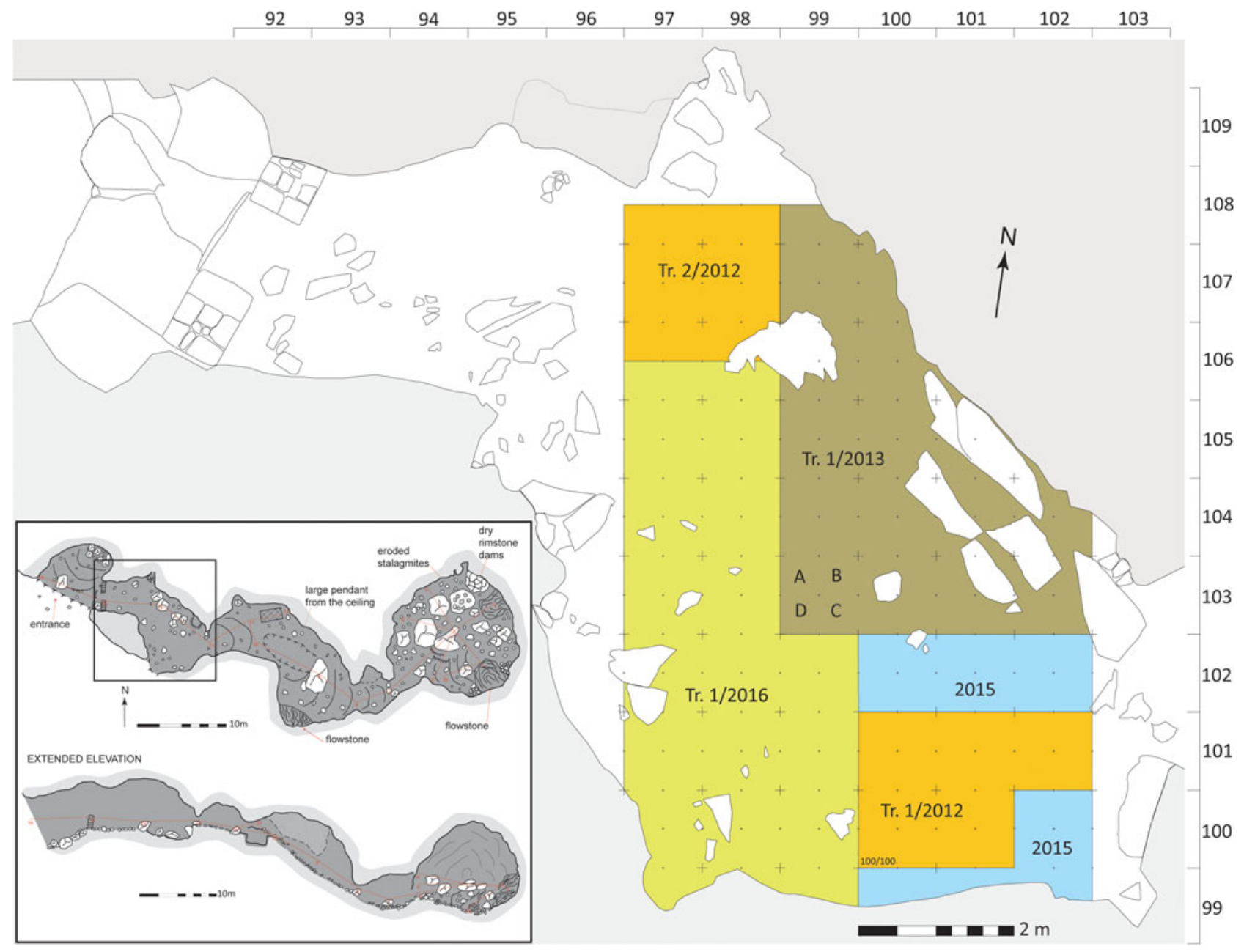

Figure 9. Vrbička cave (surveyed by J. Ćalic and P. Stošic, graphic design by Goran Dujković) and areas excavated in 2012-2017 in the first chamber of the cave.

Drawn by S. Stratton and prepared by D. Boric. 


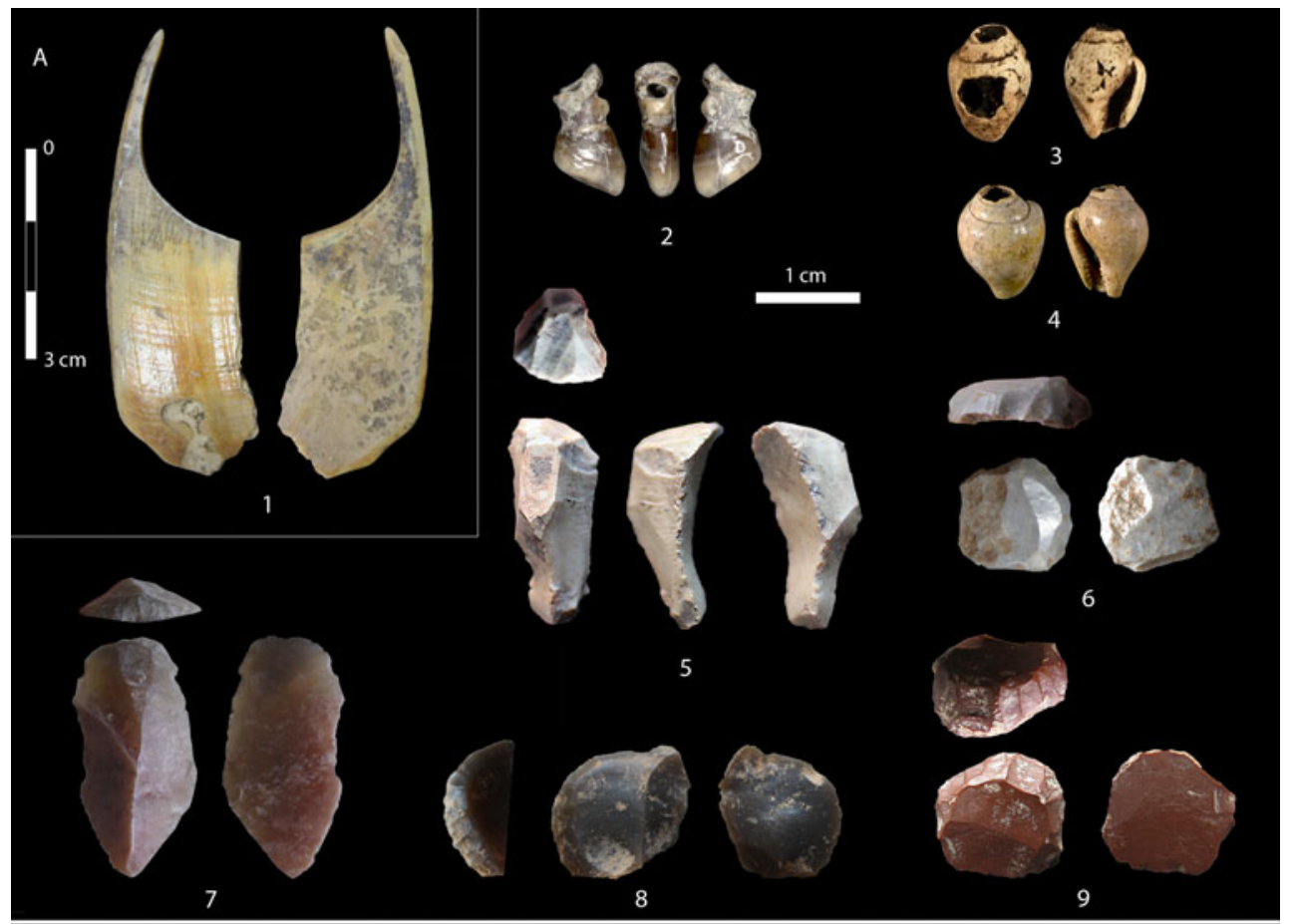

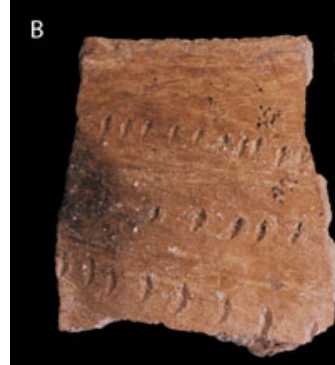

10

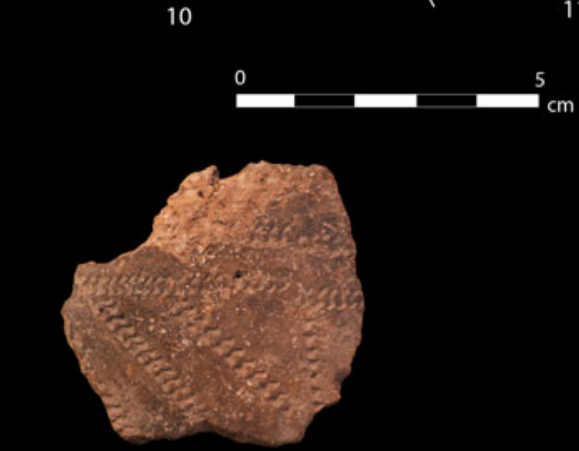

13

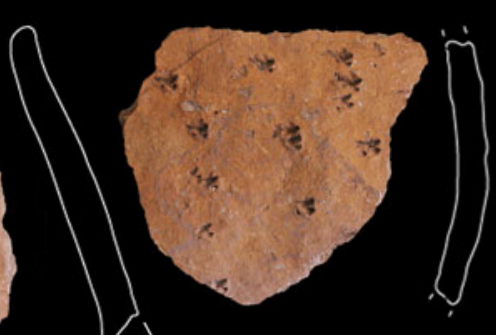

11

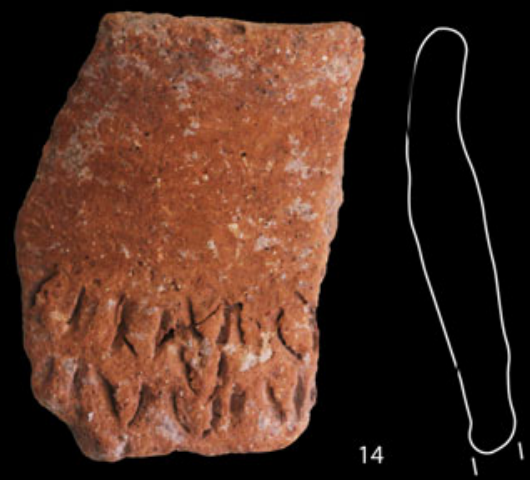

Figure 10. Mesolithic and Early Neolithic finds from Vrbicka cave. A: Mesolithic: 1: AMS-dated wild boar tusk tool (OxA-27790); 2: bead made from a pharyngeal tooth of Rutilus sp.; 3-4: Columbella rustica beads; 5-9: a selection of flint tools. B: Early Neolithic: 10-14: a selection of Early Neolithic decorated Impressed Ware.

Photographs by D. Boric and E. Cristiani. 
(Cristiani \& Borić, 2016; see also Supplementary Material 1 for methodology and harpoon technology). Here, rounding, compression marks, macro-scars, modification of the outline of the bases, and longitudinal fractures indicate that the proximal extremities of the harpoons were fixed to the shaft with a line, similarly to ethnographic detachable-head harpoons (Boas, 1888; Rudenko, 1961; Owen, 2005). Ethnographic artefacts show hafting traces that are comparable to those recognized archaeologically and which are related to repeated insertion of the proximal part of the harpoons into the shaft during use (see Pétillon, 2006: 73-75).

Perforations are a very peculiar technofunctional characteristic of the harpoons from Vruća and Odmut. In most cases, these harpoons show a single perforation located on the meso-proximal part of the shaft in an asymmetric position in relation to the harpoon width, i.e. towards the side of the barb. There are clear similarities between the harpoon specimens with perforations found at Vruća and Odmut. Only three specimens from Vruća exhibit different morphological traits (narrower blanks and absence of perforations). However, apart from one specimen (Figure 7.5), which might have come from the Late Mesolithic levels, the other two specimens come from the same Early Neolithic levels as the predominant type of harpoons. Similarly, at Odmut, the variant of harpoons with narrower blanks and absence of perforation is found both in the Mesolithic and Early Neolithic (Figure 4.9) levels. Hence, we suggest that these specimens taken together exhibit an expected variability within the same technological tradition.

Our claim that the harpoons from Odmut and Vruća are part of the same techno-morphological tradition throughout the Late Mesolithic and into the Early Neolithic is based on the co-existence of very peculiar single straight barbed specimens within both assemblages and the presence, on almost all of the harpoons recovered at the two sites, of single or double mesial, distal, and/or proximal perforation(s). Such a homogeneity in the assemblages from Vruća and Odmut is strengthened by a comparison to known contemporaneous Mesolithic examples of harpoon production in other parts of the Balkans (e.g. at Špehovka and Ljubljanica riverbed in Slovenia: Turk, 2004; Brodar \& Osole, 1979; and at Vlasac and Kula in the Danube Gorges area: Srejovic \& Letica, 1978; Vitezović, 2011) as well as detachable-head specimens documented in the eastern Alpine region of Italy (Cristiani, 2009), which all exhibit specific regional traits in harpoon manufacturing: the presence of bevelled bases and proximal gorges, the absence of single straight barbed specimens, and the absence of distal and/or proximal perforations. All the Mesolithic specimens from the Balkans and the eastern Alpine region of Italy can be characterized as detachable-head harpoons. However, we suggest that the presence of perforations on the harpoons from Vruca and Odmut could indicate the existence of a specific technological tradition with different techno-functional solutions involving different gestures of production and use.

At the site of Badanj, located to the west of Odmut $(80 \mathrm{~km})$ and Vruca $(133 \mathrm{~km})$ in the adjacent region of Herzegovina, two completely shaped unilateral antler barbed points with straight barbs and, in one case, a gorge towards the base (Supplementary Figure 5) have been found in Epipalaeolithic layers (Kujundžić, 1990), and this dating is now confirmed by direct AMS measurements (Borić et al. in press). These specimens are comparable in dimensions and technofunctional characteristics to the specimens found at Odmut and Vruća, but it is hard to speculate here about the continuity of a 
cultural tradition considering that these occurrences of barbed points are separated by several millennia.

We conclude that, from the perspective of practice theory, the existence of the same set of technological gestures and morphological traits in the process of production and use of the harpoons found at Odmut and Vruća is indicative of a single cultural tradition, transmitted through learning processes. It is, therefore, very unlikely that two different populations during the Late Mesolithic at Odmut had independently produced the same (even almost identical) types of harpoons in the course of the seventh millennium cal $\mathrm{BC}$ without a cultural transmission of knowledge and manufacturing know-how from generation to generation; it is just as unlikely that the same manufacturing tradition would independently emerge during the Early Neolithic at either Odmut or Vruca in the first centuries of the sixth millennium cal BC. The identification of the same cultural tradition, formalized in the production of these emblematic harpoons and their continuity across Late Mesolithic and Early Neolithic contexts, is particularly relevant for our further discussion about the nature of the MesolithicNeolithic transition in the wider regional context.

\section{The Eastern Adriatic and wider regional patterns}

In light of the evidence presented here, let us return to Gurova \& Bonsall's (2014) model mentioned earlier. They argue that the invisibility of Mesolithic sites in the Balkan interior should be taken as evidence of a genuine settlement pattern owed to the spread of a dense Holocene forest canopy that reduced the ungulate biomass and overall productivity of these zones for human exploitation, and stress that the focus was on aquatic resources as the dominant form of Mesolithic lifeways. The model does not seem to take into account the evidence (highlighted here) from Mesolithic sites in the western Balkans distant from the coastal areas in the mountainous parts of the region. Here and elsewhere it may be unhelpful to reduce the dimensions of Mesolithic existence to a single narrative and character. As we have shown with the examples of sites discussed, various kinds of Mesolithic adaptations over relatively small distances appear to have existed, as exemplified by the occurrence of harpoons at some sites (Odmut and Vruća) and their complete absence at others (Vrbička, Crvena Stijena, Medena Stijena, Seocka). Furthermore, while aquatic resources were exploited along with dominant forest game and smaller food 'packages', such as pond tortoise or land snails, there are sites with no evidence of aquatic exploitation in the faunal assemblage; this is the case of Vrbička, where hazelnut and perhaps also other plant resources along with land snails and forest game animals composed the bulk of the Mesolithic forager diet. Furthermore, contrary to suggestions that Mesolithic groups were isolated and despite changes in patterns of flint procurement when compared to the Late Upper Palaeolithic, we have uncovered at Vrbička unequivocal evidence of contact over long distances (c. $300 \mathrm{~km}$ ) between different communities with a shared symbolic or ornamental vocabulary at the turn of the eighth to seventh millennia cal BC.

At Vrbička and possibly also Vruća, the current evidence suggests a chronological gap between the Late Mesolithic (around the end of the eighth and beginning of the seventh millennia cal $\mathrm{BC}$ ) and the Early Neolithic (early sixth millennium cal BC) occupation, leaving the greatest part of the seventh millennium unaccounted for. This apparent temporal gap between the latest 
Mesolithic and Early Neolithic occupation of various cave sites (which remain the main repositories of Mesolithic material but also the greatest part of Neolithic sequences) is not new in the region. Several authors have argued that a hiatus in the coverage of the Late Mesolithic in the Mediterranean hinterland zones point to a region-wide population decline in the course of the seventh millennium cal BC, which facilitated a replacement of the local foragers by farmers from elsewhere at the end of the millennium (e.g. Biagi \& Spataro, 2001; but see Mlekuž et al., 2008). The dating evidence from the entire eastern Adriatic region has indeed suggested a pattern of occupation more visible in the tenth and ninth millennia cal BC (Forenbaher \& Miracle, 2005, 2006; Forenbaher et al., 2013), which is further strengthened by recent Early Mesolithic dates from Crvena Stijena and Seocka in Montenegro (Table 1). However, the AMS dates from Vrbička and Vruća presented here put the occupation of these two sites either at the end of the eighth or the beginning of the seventh millennium cal BC. Furthermore, the largest number of radiocarbon dates in the long-lived Mesolithic-Neolithic sequence at Odmut, but also at Crvena Stijena, cover exactly the seventh millennium cal BC (Table 1). There is now also strong evidence that the tradition of harpoon manufacturing and use established at Odmut by the early seventh millennium cal $\mathrm{BC}$ continued to be relevant in the Early Neolithic at the beginning of the sixth millennium cal $\mathrm{BC}$. This is confirmed by the presence of the same curated barbed point tradition in the Early Neolithic levels at Vruca (Supplementary Figure 6). Other strands of evidence (knapped stone, fauna) from both sites also indicate that these transitional assemblages were mixed in nature, with cultural traits and subsistence patterns exhibiting both continuities with the preceding Mesolithic occupation and introduction of some novel elements from Neolithic cultural repertoires.

Earlier, we have suggested some of the possible reasons for the frustrating absence of Mesolithic sites in Montenegro, that is a combination of the ephemeral nature of occupation and taphonomic problems related to cave deposits. There are at least two other reasons for the absence of openair sites in the context of the eastern Adriatic region as well as in other environmentally similar contexts across southeastern Europe. The first relates to the role erosional events and sedimentation plays in masking the visibility of many Mesolithic but also some Early Neolithic sites in lowland areas along valley floors. An example of this process is the Middle Neolithic site of Kula Atlagić in the Zadar plain of Dalmatia, Croatia, found $1.5 \mathrm{~m}$ below alluvial sediments (Chapman et al., 1996: 258-59). The almost complete absence of open-air Mesolithic or Early/ Middle Neolithic sites in Montenegro, except in the north where only two openair Early/Middle Neolithic sites (Kremeštice near Berane, and Doganje near Pljevlja; Borovinić et al., 2017: 234) are known (Figure 1), could stem from the same natural formation processes.

We contend that the second major reason for the observed bias is linked to the lack of training or research focus among many south-eastern European archaeologists who conducted regional surveys in the past to recognize lithics rather than ceramics. In Montenegro, in particular in the higher altitude zones of the Dinaric Alps, such as the Durmitor Mountain where several glacial lakes are known (Hughes et al., 2011), we may perhaps in the future expect a pattern of possibly seasonally occupied Mesolithic sites comparable to instances of similar post-Pleistocene adaptations and recolonization of high altitude zones, for example 
in the Italian (e.g. Biagi, 1993; Fontana et al., 2016) and Austrian Alps (e.g. Schäfer, 2011). Hence it seems reasonable to expect a pattern of more widespread (Late) Mesolithic settlement than is currently known.

\section{Conclusions}

Direct AMS-dating of harpoons, which form part of a curated and standardized Mesolithic hunting toolkit and a key fossile directeur in the Dinaric Alps of Montenegro, enabled us to establish that this local forager technological tradition survived into the Early Neolithic period. The introduction of Neolithic novelties in the hinterland of the southern parts of the eastern Adriatic should be dated at least a century or two earlier than previously proposed by Forenbaher and Miracle (2005, 2006) in their two-staged model for the spread of farming and herding in this regional context. While Impressed Ware and some domesticates were introduced into the hinterland of the Adriatic catchment zone from around $6000 \mathrm{cal} \mathrm{BC}$, cultural changes and adoption of novelties were piecemeal, probably pointing to population continuities from the Mesolithic to the Neolithic. Future discoveries of Mesolithic and Neolithic human remains, which are currently non-existent in Montenegro, along with their aDNA analysis (now available for other areas of southeastern Europe: Mathieson et al., 2018), would be crucial for resolving this issue.

We suggest that the evidence presented here best fits the individual frontier mobility' model (Zvelebil \& Lillie, 2000). There may have been newly-founded, pioneer settlements, both in caves and on open-air locations, of Neolithic immigrants closer to the Adriatic coast, assuming their maritime spread, or in other ecological niches across the region. A case in point is the existence of the probably newly-established Early Neolithic cave sites of Spila near Perast in the Bay of Kotor and Koronina near Cetinje (Figure 1) (Marković, 1985; Borovinić et al., 2017), which are currently undated. Finding and investigating similar sites must remain a priority for future research in order to elucidate further the nature of the Mesolithic-Neolithic transition in this regional context.

\section{SuPPlementary Material}

To view supplementary material for this article, please visit https://doi.org/10.1017/ eaa.2019.14.

\section{ACKNOWLEDGEMENTS}

We acknowledge funding received for different stages of this project through various grants: Marie Curie Intra-European Fellowship-IEF n. 273575, ERC Starting Grant Project G.A. HIDDEN FOODS 639286, McDonald Institute for Archaeology grants at the University of Cambridge (2012-2013, 2015-2016) to Emanuela Cristiani; Cardiff University Study Abroad (2012, 2016) and Institute for Field Research (2017) field schools to Dušan Borić. Dušan Borić acknowledges the fellowship in 2017-2018 at the Italian Academy for Advanced Studies in America at Columbia University in the City of New York, during which this article was written. We are also grateful to Robert Whallon and Preston Miracle for their kind permission to use images of two barbed points from Badanj, to Dušan Mihailović and Dejan Gazivoda for their help in setting up our project in Montenegro, and Alasdair Whittle, Doug Price, and five anonymous reviewers for their critical comments on earlier drafts of the article. 


\section{REFERENCES}

Baković, M., Mihailović, B., Mihailović, D., Morley, M., Vušović-Lučić, Z., Whallon, R. \& Woodward, J. 2009. Crvena Stijena Excavations 2004-2006, Preliminary Report. Journal of Eurasian Prehistory, 6: 3-31.

Basler, Đ., ed. 1975. Crvena Stijena - Zbornik radova. Nikšic: Zajednica kulturnih ustanova.

Biagi, P. 1993. Mesolithic Exploitation of the Highland Zone: A Case Study for the Southern Alps. Preistoria Alpina, 28: 367-72.

Biagi, P. \& Spataro, M. 2001. Plotting the Evidence: Some Aspects of Radiocarbon Chronology of the Mesolithic-Neolithic Transition in the Mediterranean Basin. Atti della Società per la Preistoria e Protoistoria della Regione Friuli-Venezia Giulia, 12: 15-54.

Boas, F. 1888. The Central Eskimo. In: Bureau of American Ethnology, Sixth Annual Report. Washington, D.C.: The Smithsonian Institution, pp. 409-669.

Bonsall, C. 2008. The Mesolithic of the Iron Gates. In: G.N. Bailey \& P. Spikins, eds. Mesolithic Europe. Cambridge: Cambridge University Press, pp. 238-79.

Borić, D. 2005. Deconstructing Essentialisms: Unsettling Frontiers of the MesolithicNeolithic Balkans. In: D. Bailey, A. Whittle \& V. Cummings, eds. (Un) settling the Neolithic. Oxford: Oxbow Books, pp. 16-31.

Borić, D. 2011. Adaptations and Transformations of the Danube Gorges Foragers (c. 13,000-5500 cal BC): An Overview. In: R. Krauß, ed. Beginnings: New Research in the Appearance of the Neolithic Between Northwest Anatolia and the Carpathian Basin. Rahden: Marie Leidorf, pp. 157-203.

Borić, D. 2016. Deathways at Lepenski Vir: Patterns in Mortuary Practice. Belgrade: Serbian Archaeological Society.

Borić, D. \& Cristiani, E. 2016. Social Networks and Connectivity Among the Palaeolithic and Mesolithic Foragers of the Balkans and Italy. In: R. Krauß \& H. Floss, eds. Southeast Europe before the Neolithisation. Tübingen: University of Tübingen, pp. 73-112.

Borić, D., Cristiani, E., Pravidur, A., Marić, A. and Whallon, R., in press.
Osseous Tools and Personal Ornaments from the Epigravettian Sequence at Badanj. Glasnik Zemaljskog muzeja Bosne i Hercegovine.

Borić, D., French, C.A.I., Stefanović, S., Dimitrijević, V., Cristiani, E., Gurova, M., et al. 2014. Late Mesolithic Lifeways and Deathways at Vlasac (Serbia). Journal of Field Archaeology, 39: 4-31. https://doi.org/ 10.1179/0093469013Z.00000000070

Borovinić, N., Baković, M. \& Whallon, R. 2017. The Ceramic Layers at Crvena Stijena in their Ecological and Cultural Context. In: R. Whallon, ed. Crvena Stijena in Cultural and Ecological Setting: Multidisciplinary Archaeological Research in Montenegro. Podgorica: Montenegrin Academy of Sciences and Arts, pp. 230-56.

Brodar, M. \& Osole, F. 1979. Paleolitske i mezolitske regije i kulture u Sloveniji. In: A. Benac, ed. Praistorija jugoslavenskib zemalja, Paleolitsko i mezolitsko doba, vol. I. Sarajevo: Akademija nauka i umetnosti Bosne i Hercegovine, pp. 159-94.

Bronk Ramsey, C. \& Lee, S. 2013. Recent and Planned Developments of the Program OxCal. Radiocarbon, 55: 720-30. https://doi.org/10.2458/azu_js_rc.55.16215

Chapman, J., Shiel, R. \& Batović, Š. 1996. The Changing Face of Dalmatia: Archaeological and Ecological Studies in a Mediterranean Landscape. London: Leicester University Press.

Cristiani, E. 2009. Morphological and technofunctional analysis of osseous artefacts from the Mesolithic levels of Pradestel Rockshelter (Italy). Preistoria Alpina, 44: 181-202.

Cristiani, E. \& Borić, D. 2012. 8500-YearOld Garment Embroidery from the Late Mesolithic Site of Vlasac (Serbia): Technological, Use-Wear and Residue Analyses. Journal of Archaeological Science, 39: 3450-69. https://doi.org/10.1016/j.jas. 2012.05.016

Cristiani, E. \& Borić, D. 2016. Harpoons from Odmut, Montenegro: Contextual, Technological, and Use-Wear Analyses. Quaternary International, 423: 166-92. https://doi.org/10.1016/j.quaint.2015.11.010

Đuričić, Lj. 1997. Vruća pećina. Starinar, 48: 195-99.

Eichmann, W.J., Kertész, R. \& Marton, T. 2010. Mesolithic in the LBK Heartland of Transdanubia, Western Hungary. In: D. 
Gronnenborn \& J. Petrasch, eds. The Spread of the Neolithic to Central Europe. Mainz: Römisch-Germanisches Zentralmuseum, pp. 211-33.

Fontana, F., Visentin, D. \& Wierer, U. eds. 2016. MesoLife: A Mesolithic Perspective on Alpine and Neighbouring Territories. Preistoria Alpina, 48: 7-10.

Forenbaher, S. \& Miracle, P.T. 2005. The Spread of Farming in the Eastern Adriatic. Antiquity, 79: 514-28. https:// doi.org/10.1179/1461957113Y.0000000038

Forenbaher, S. \& Miracle, P. 2006. Pupićina Peć and the Spread of Farming in the Eastern Adriatic. In: P.T. Miracle \& S. Forenbaher, eds. Prehistoric Herders of Northern Istria: The Archaeology of Pupicina Cave 1. Pula: Archaeological Museum of Istria, pp. 483-530.

Forenbaher, S., Kaiser, T. \& Miracle, P.T. 2013. Dating the East Adriatic Neolithic. European Journal of Archaeology, 16: 589-609. https://doi.org/10.1179/ 1461957113Y.0000000038

Franco, C. 2011. La fine del Mesolitico in Italia: Identità culturale e distribuzione territoriale degli ultimi cacciatori-raccoglitori. Trieste: Società per la preistoria e protostoria della regione Friuli-Venezia Giulia.

Galanidou, N. 2011. Mesolithic Cave Use in Greece and the Mosaic of Human Communities. Journal of Mediterranean Archaeology, 24: 219-42. https://doi.org/ 10.1558/jmea.v24i2.219

Gurova, M. \& Bonsall, C. 2014. 'Pre-Neolithic' in Southeast Europe: A Bulgarian Perspective. Documenta Praehistorica, 15: 95-109. https://doi.org/10.4312/dp.41.5

Harrold, F., Russell, N. \& Wickens, J. 2017. The Mesolithic of Konispol Cave, Albania. Iliria, 40: 7-38. https://doi.org/ 10.1002/(SICI)1520-6548(199806)13: 5<501::AID-GEA3>3.0.CO;2-4

Hauck, T.C., Ruka, R., Gjipali, I., Richter, J. \& Nolde, N. 2017. The 'German Albanian Palaeolithic' Programme (GAP): A Status Report. In: Vocation préhistoire, bommage à Jean-Marie Le Tensorer. Liège: Etudes et Recherches Archéologiques de l'Université de Liège, pp. 159-73.

Hughes, P.D., Woodward, J.C., van Calsteren, P.C. \& Thomas, L.E. 2011. The Glacial History of the Dinaric Alps, Montenegro. Quaternary Science Reviews, 30: 3393-412.
Komšo, D. 2006. The Mesolithic in Croatia. Opuscula Archaeologica, 35: 55-92.

Kozłowski, J.K. 1999. Gravettian/ Epigravettian Sequences in the Balkans: Environment, Technologies, Hunting Strategies and Raw Material Procurement. In: G.N. Bailey, E. Adam, C. Perlès, E. Panagopoulou \& K. Zachos, eds. The Palaeolithic Archaeology of Greece and Adjacent Areas. London: British School at Athens, pp. 319-29.

Kozłowski, J.K. \& Kozłowski, S.K. 1982. Lithic Industries from the Multi-Layer Mesolithic Site, Vlasac, in Yugoslavia. In: J.K. Kozłowski, ed. Origin of the Chipped Stone Industries of the Early Farming Cultures in the Balkans. WarszawaKrakow: Panstwowe Wydawnictwo Naukowe, pp. 11-109.

Kozłowski, J.K., Kozłowski, S.K. \& Radovanović, I. 1994. Meso- and Neolithic Sequences of the Odmut Cave (Montenegro). Warsaw: University of Warsaw.

Kujundžić, Z. 1990. Najstariji ribolovci u kanjonu Bregave. Slovo Gorčina, 18: 23-25.

Magyari, E., Gaydarska, B., Pettitt, P. \& Chapman, J. 2013. Palaeo-Environments of the Balkan Lateglacial and their Potential: Were Humans Absent from the Garden of Eden? Bulgarian e-Journal of Archaeology, 3: 1-30.

Marković, C. 1974. The Stratigraphy and Chronology of the Odmut Cave. Archaeologia Iugoslavica, 15: 7-12.

Marković, C. 1985. Neolit Crne Gore. Beograd: Centar za arheološka istraživanja Filozofskog fakulteta.

Mathieson, I., Alpaslan-Roodenberg, S., Posth, C., Szécsényi-Nagy, A., Rohland, N., Mallick, S., et al. 2018. The Genomic History of Southeastern Europe. Nature, 555: 197-203. https://doi.org/10. 1038/nature25778

Mercier, N., Rink, W.J., Rodrigues, K., Morley, M.W., Vander Linden, M. \& Whallon, R. 2017. Radiometric Dating of the Crvena Stijena Sequence. In: R. Whallon, ed. Crvena Stijena in Cultural and Ecological Setting: Multidisciplinary Archaeological Research in Montenegro. Podgorica: Montenegrin Academy of Sciences and Arts, pp. 140-49.

Mihailović, D. 1996. Upper Palaeolithic and Mesolithic Chipped Stone Industries from the Rockshelter of Medena Stijena. In: D. 
Srejović, ed. Prehistoric Settlements in Caves and Rock-shelters of Serbia and Montenegro. Belgrade: Centre for Archaeological Research, Faculty of Philosophy, pp. 9-60.

Mihailović, D. 2001. Technological Decline of the Early Holocene Chipped Stone Industries in South-East Europe. In: R. Kertész \& J. Makkay, eds. From the Mesolithic to the Neolithic. Budapest: Archaeolingua, pp. 339-47.

Mihailovic, D. 2007. Social Aspects of the Transition to Farming in the Balkans. Documenta Praehistorica, 34: 73-88. https://doi.org/10.4312/dp.34.6

Mihailović, D. 2009. Upper Palaeolitbic and Mesolithic Chipped Stone Industries from Crvena Stijena. Belgrade: Centre for Archaeological Research, Faculty of Philosophy.

Miracle, P. 1997. Early Holocene Foragers in the Karst of Northern Istria. Poročilo o raziskovanju paleolita, neolita in eneolita $v$ Sloveniji, 24: 43-61.

Miracle, P. 2007. The Late Glacial 'Great Adriatic Plain': 'Garden of Eden' or 'No Man's Land' during the Epipaleolithic? A View from Istria (Croatia). In: R. Whallon, ed. Late Palaeolithic Environments and Cultural Relations Around the Adriatic (BAR International Series 1716). Oxford: Archaeopress, pp. 41-51.

Miracle, P., Galanidou, N. \& Forenbaher, S. 2000. Pioneers in the Hills: Early Mesolithic Foragers at Šebrn Abri (Istria, Croatia). European Journal of Archaeology, 3: 293-329. https://doi.org/10.1177/ 146195710000300301

Mlekuž, D., Budja, M., Payton, R., Bonsall, C. \& Gašparič, A.Ž. 2008. Reassessing the Mesolithic/Neolithic 'Gap' in Southeast European Cave Sequences. Documenta Praehistorica, 35: 237-51. https://doi.org/10.4312/dp.35.18

Owen, L. 2005. Distorting the Past. Gender and the Division of Labor in the European Upper Palaeolithic. Tübingen: Kerns.

Pétillon, J.-M. 2006. Des Magdaléniens en armes: Technologie des armatures de projectile en bois de cervidé du Magdalénien Supérieur de la grotte d'Isturitz (PyrénéesAtlantiques) (Artefacts, 10). Treignes: Centre d'études et de documentation archéologiques.

Pétillon, J.-M. 2008. What Are these Barbs for? Preliminary Reactions on the Function of the Upper Magdalenian Barbed Weapon Tips. Palethnologie, 1: 66-97.

Pilaar Birch, S.E. \& Miracle, P.T. 2017. Human Response to Climate Change in the Northern Adriatic During the Late Pleistocene and Early Holocene. In: G. Monks, ed. Climate Change and Past Human Responses: An Archaeozoological Perspective. New York: Springer, pp. 87-100.

Pilaar Birch, S.E. \& Vander Linden, M. 2018. A Long Hard Road... Reviewing the Evidence for Environmental Change and Population History in the Eastern Adriatic and Western Balkans During the Late Pleistocene and Early Holocene. Quaternary International, 465: 177-91. https://doi.org/ 10.1016/j.quaint.2016.12.035

Rudenko, S.I. 1961. Ancient Culture of Bering Sea and the Eskimo Problem. Toronto: University of Toronto Press.

Schäfer, D. ed. 2011. Das MesolitbikumProjekt Ullafelsen 1 (Mensch und Umwelt im Holozän Tirols 1). Innsbruck: Philipp von Zabern.

Srejović, D. 1974. The Odmut Cave: A New Facet of the Mesolithic Culture of the Balkan Peninsula. Archaeologia Iugoslavica, 15: 3-7.

Srejović, D. \& Letica, Z. 1978. Vlasac. Mezolitsko naselje u Đerdapu (I arheologija). Beograd: Srpska akademija nauka i umetnosti.

Turk, I. 2004. Brief History of Research of the Mesolithic in Slovenia. In: I. Turk, ed. Viktorjer spodmol and Mala Triglavea. Contributions to Understanding the Mesolithic Period in Slovenia. Ljubljana: Institute of Archaeology, pp. 15-20.

Vander Linden, M., Marriner, G., Orton, D., De Vareilles, A., Edinborough, K., Daković, G., et al. 2014. Preliminary Report on the Excavations in Seocka Pećina, Montenegro (September 2013). In: D. Mihailović, ed. Palaeolitbic and Mesolithic Research in the Central Balkans. Belgrade: Serbian Archaeological Society, pp. 153-58.

Vitezović, S. 2011. The Mesolithic Bone Industry from Kula. Before Farming, 2011 (3): 1-21.

Whallon, R. ed. 2017. Crvena Stijena in Cultural and Ecological Setting: Multidisciplinary Archaeological Research in Montenegro. Podgorica: Montenegrin Academy of Sciences and Arts. 
Willis, K.J. 1994. The Vegetational History of the Balkans. Quaternary Science Reviews, 13: 769-88. https://doi.org/10.1016/02773791(94)90104-X

Zvelebil, M. \& Lillie, M. 2000. Transition to Agriculture in Eastern Europe. In: T.D. Price, ed. Europe's First Farmers. Cambridge: Cambridge University Press, pp. 57-92.

\section{Biographical Notes}

Dušan Borić is a researcher at the Italian Academy for Advanced Studies in America, Columbia University in the City of New York, USA, with research interests in different aspects of European and Near Eastern prehistory, bioarchaeology, and archaeological and anthropological theory.

Address: The Italian Academy for Advanced Studies in America, Columbia University, 1161 Amsterdam Avenue, Mail Code 1401, New York, NY 10027, USA. [email: db2128@columbia.edu] ORCID: 00000003-0166-627X

Nikola Borovinić is an archaeologist at the Centre for Conservation and Archaeology of Montenegro, Cetinje, Montenegro, interested in the study of the early prehistory of the Balkans.

Address: Centre for Conservation and Archaeology of Montenegro, Bajova 150, 81250 Cetinje, Montenegro. [email: nikola_borovinic@yahoo.com]

Ljiljana Đuričić is a researcher emeritus at the Archaeological Collection in the Faculty of Philosophy, University of Belgrade, Serbia, with research interests in lithics and the Palaeolithic and Mesolithic periods in the Balkans.
Address: Archaeological Collection, Faculty of Philosophy, University of Belgrade, Čika Ljubina 18-20, 11000 Belgrade, Serbia. [email: ljdjuric@f.bg.ac.rs]

Jelena Bulatovic is a researcher at the Laboratory for Bioarchaeology, Faculty of Philosophy, University of Belgrade, Serbia, specializing in zooarchaeology.

Address: Laboratory for Bioarchaeology, Faculty of Philosophy, University of Belgrade, Čika Ljubina 18-20, 11000 Belgrade, Serbia. [email: j.bulatovic@yahoo. com]

Katarina Gerometta is a lecturer at the Faculty of Humanities, Juraj Dobrila University of Pula, Croatia, specializing in geoarchaeology and micromorphology, with a particular focus on the study of cave sediments.

Address: Department of Archaeology, Faculty of Philosophy, Juraj Dobrila University of Pula, Ivana Matetica Ronjgova 1, 52100 Pula, Croatia. [email: katarina.gerometta@unipu.hr] ORCID: 0000-0002-9601-4911

Dragana Filipovic is a researcher at the Institute for Pre- and Protohistory, Kiel University, Kiel, Germany, and the Institute for Balkan Studies, Serbian Academy of Sciences and Arts, Belgrade, Serbia, specializing in the study of macrobotanical remains.

Address: Institute for Pre- and Protohistory, Johanna-Mestorf Str. 2-6, Kiel University, Kiel, Germany 24118/ Institute of Balkan Studies, Serbian Academy of Sciences and Arts, 11000 
Belgrade, Serbia. [email: d.filipovic@ufg. uni-kiel.de] ORCID: 0000-0003-43892945

Ethel Allué is a professor at the Universitat Rovira i Virgili in Tarragona, Spain, with a specialization in carpological studies.

Address: Àrea de Prehistòria, Universitat Rovira i Virgili (URV), Av. Catalunya 35, 43002 Tarragona, Spain; IPHES, Institut Català de Paleoecologia Humana i Evolució Social, Zona Educacional 4 Campus Sescelades URV (Edifici W3), 43007 Tarragona, Spain. [email: eallue@ iphes.cat] ORCID: 0000-0002-24310025

Zvezdana Vušović-Lučić is an archaeologist emeritus at the Centre for Culture and National Museum in Nišić,
Montenegro, with research interests in Montenegrin prehistory.

Address: IV Crnogorske 4/67, 81400 Nikšić, Montenegro. [email: zvusovic@gmail.com]

Emanuela Cristiani is an associate professor at La Sapienza University in Rome, Italy. She specializes in use-wear, residue, and technological analyses of different classes of archaeological material, with a particular interest in the study of prehistoric ornaments and the role of plant foods in prehistoric human diets through the study of starch grains in dental calculus and ground stones.

Address: DANTE, Diet and Ancient Technology Laboratory, Dipartimento di Scienze Odontostomatologiche e Maxillo Facciali, La Sapienza University, Via Caserta 6, 00161 Rome, Italy. [email: emanuela.cristiani@uniroma1.it] ORCID: 0000-0002-2748-9171.

\section{A l'orée du Néolithique: les derniers chasseurs-cueilleurs et les premiers paysans des Alpes dinariques au Monténégro}

Dans cet article, nous présentons une synthèse des nouvelles données concernant le Mésolithique dans les Alpes dinariques du Monténégro. Cette région est extrêmement bien placée en Europe du sud-est pour étudier les chasseurs-cueilleurs du début de l'Holocène et la nature de la transition envers les modes de vie du Néolithique à la fin du septième et au début du sixième millénaire cal BC grâce à ses paysages biodiversifiés et ses reliefs karstiques. Nous soutenons que des harpons découverts sur deux sites différents dans cette région sont symptomatiques d'une technologie conservatrice qui a ses racines dans une tradition mésolithique locale. Le maintien de cette panoplie de chasse standard au Néolithique est un indice important qui nous renseigne sur le caractère de la transition du Mésolithique au Néolithique. Notre étude de cas sert également de tremplin pour traiter des questions d'ampleur plus large concernant la visibilité archéologique et les modes d'occupation au Mésolithique dans l'ensemble de l'Europe du sud-est. Translation by Madeleine Hummler

Mots-clés: harpons, transition Mésolithique-Néolithique, contacts entre chasseurs-cueilleurs et agriculteurs, Alpes dinariques, Monténégro, Adriatique orientale 


\section{Abschuss ins Neolithikum: die letzten Sammler und Jäger und die ersten Bauern in den dinarischen Alpen im Montenegro}

In diesem Artikel werden neue Erkenntnisse über das Mesolithikum in den dinarischen Alpen von Montenegro zusammenfassend behandelt. Dieses Gebiet bietet mit seinen biologisch vielfältigen Landschaften und Karstrelief sehr günstige Bedingungen für die Untersuchung der Sammler und Wildbeuter des früben Holozäns in Südosteuropa und über die Natur des Übergangs zu neolithischen Lebensweisen am Ende des siebten und am Anfang des sechsten Jahrtausend cal BC. Wir sind der Meinung, dass Harpunen, die auf zwei verschiedenen Fundstellen in der Gegend gefunden worden sind, eine betreute Technologie, die in einer lokalen mesolithischen Tradition verwurzelt war, darstellt. Die Weiterbenutzung dieses standardisierten Werkzeugsatzes im Neolitbikum ist ein wichtiger Hinweis über den Charakter des Übergangs vom Mesolithikum zum Neolithikum. Unsere Fallstudie ist auch Anlass für eine Betrachtung von weiter reichenden Fragen der Sichtbarkeit und Arten der mesolithischen Besiedlung in Südosteuropa. Translation by Madeleine Hummler

Stichworte: Harpunen, Übergang vom Mesolithikum zum Neolithikum, Kontakt zwischen Sammler/Jäger und Bauern, dinarische Alpen, Montenegro, ostadriatisches Gebiet 